\title{
The innovation facilitator: characteristics and importance for innovation teams
}

\author{
Mikael Johnsson \\ mikael.johnsson@bth.se | Blekinge Institute of Technology, 37179 Karlskrona, Sweden
}

\begin{abstract}
This research develops the understanding of the innovation facilitator's (facilitator) role in terms of inexperienced innovation teams in an industrial context. Qualitative data was collected from three X-functional innovation teams' members and their sponsor to identify the requirements for a facilitator. Forty characteristics were identified and charted in an innovation process. Significant findings, contributing to prior research, are that the facilitator's presence and involvement in the innovation teams was crucial in the pre-phase and first phase of the innovation process due to the very high complexity; in these phases, personal characteristics as well as skills in, for example, facilitating, teaching, coaching, and group dynamics were central. The importance of the pre-phase was unexpected, resulting in an extended innovation process, during which an initial preparation phase has been added to the traditional innovation process. This knowledge is applicable, for example, when creating and educating new innovation teams within an organization. Future research is suggested.
\end{abstract}

Keywords. Innovation Facilitator; Innovation Team; Innovation Management; Product Development; Innovation Process.

Cite paper as: Johnsson, M., (2018). The innovation facilitator: characteristics and importance for innovation teams, Journal of Innovation Management, www.open-jim.org, 6(2), 12-44. http://hdl.handle.net/10216/113222 


\section{Introduction}

This research aims to gain knowledge about the innovation facilitator, that is, a person who is in the position of supporting innovation teams to both conduct and learn innovation work from ongoing innovation projects, without driving or managing the work him- or herself. The background to this study is prior research stating that there is a need for increased speed when conducting innovation work to meet shorter product life cycles (Barczak et al., 2009; Chen et al., 2009; Menon et al., 2002). Nowadays it is well known that innovative organisations are built on the empowerment of and trust in the employees; the leadership should be transparent and encourage innovative behaviour to enhance both individual creativity and the teams' ability to evaluate, expand, and refine new knowledge (Mitchell and Boyle, 2008; Schraub et al., 2014). Prior research also claims that high involvement of employees who are not a part of R\&D or development is one key to increased innovation (Bessant, 2003; Xu et al., 2006). One practical way to involve employees is to create $\mathrm{X}$-functional innovation teams that can reach out in their networks to involve co-workers or external resources (e.g., McGreevy, 2006a: 2006b; O'Connor and McDermott, 2004; West el al, 2004). At the same time, previous research demonstrates that innovation teams based on inexperienced members have performance problems due to, for example, lack of knowledge and experience regarding innovation work (Karlsson et al., 2010; Kristiansen and Bloch-Poulsen, 2010). This deficiency relates to the complex situation innovation teams need to handle when innovating, as innovation work span from ideation all the way to commercialisation (Johnsson, 2014; Kesting and Ulhöj, 2010; Lee and Sukoco, 2011; Scozzi and Garavelli, 2005).

Previous research on successful teamwork has revealed three approaches. One approach is that successful teams have a mental model that unites the team members' mind-set in, for example, goals and purpose of the project. It is argued that team leaders have a big impact on providing the mental models in which the key factors for success are related to a context in which the team could focus on the "here and now" and the future goal simultaneously (Davison and Blackman, 2005). Another approach is that innovative leadership is the key, in which the team leader handles the sequences of divergent and convergent thinking, deals with the different iterations and loops in the innovation process, works with metaphors and analogies in the search for new ideas by encouraging wild ideas and stimulating out-of-the-box thinking. This approach also requires evaluation, the judgement of new ideas during the convergent stages, and the creation of an environment for social cohesion and work with limited resources (Akbar and Tzokas, 2013; Buijs, 2007; Büschgens et al., 2013). A third approach is to identify innovation champions as enablers of innovation within organisations (Radnor and Robinson, 2000). They have proved to be successful in managing and executing innovation projects when the innovation outcomes are more important than what processes to use or follow (Dulaimi et al., 2004; Gamatese and Hallowell, 2011).

This leads to the problem of teaching innovation teams how to conduct innovation work in practice. Attempts to teach innovation teams through external innovation drivers show positive results in innovation output but not in increased innovation-related knowledge. Hallgren (2009) created innovation steering groups and supported them in their innovation projects. Johnsson et al. (2010) revealed that an external innovation driver should preferably be a person who has experience in practical innovation work in accordance with the uncertain innovation process; 
is socially competent, opportunity driven, and flexible; and has the ability to establish trust. Further, the innovation driver must have a holistic overview of the company's situation; be familiar with innovation strategies, intellectual property rights, product portfolios, and changing management; and be open for project changes. Both Hallgren and Johnsson et al. experienced that there were positive results in terms of innovation output; however, the learning effects were poor, and the innovation activities stopped shortly after that the knowledgeable persons left the organizations. In previous research on factors that enable innovation teams' innovation work (Johnsson, 2016a; 2016b), it was also identified that that the facilitator had an unexpected impact and effect on the teams. Therefore, it is of interest to explore the facilitator to gain knowledge of required characteristics and of when in the innovation projects the facilitator is most needed, if he or she is needed at all. Even though recent research suggests that facilitators for innovation include not only the facilitator him-or herself but also the spatial environment and factors as e.g. culture and policy setting (Brenner and Broekel, 2011), this research focuses on the facilitator as an individual.

\section{Literature review and research gap}

A literature study was conducted to clarify prior research in the area. This section presents research covering the innovation facilitator, innovation competence, the innovation process, and the identified research gap.

The innovation facilitator (facilitator) is defined as a person who educates, advocates, and advises. He or she is also responsible for raising the organization's awareness of the importance of innovation, standardising and communicating a vocabulary of innovation, providing a set of tools, and developing training activities (Andrew and Sirkin, 2008). In contrast to the innovation champion, who actively and enthusiastically promotes innovations through the crucial organisational stages, converting organisational issues to his or her advantage (Howell et al., 2004), the facilitator's role is to guide the complex and non-linear innovation process with various overlapping circles of individuals, teams, divisions, and departments (Hunter and Cushenbery, 2011).

The facilitator is especially important when an organisation needs to change attitudes and learn new skills or behaviours. Being a facilitator is a long-term commitment that may span several years but eventually becomes unnecessary to the innovation team's work when constant, intensive, companywide education is no longer required (Andrew and Sirkin, 2008). However, the role of the facilitator is complex where operational developer (OD) practitioners are suggested to facilitate innovation (Barnes and Francis, 2006), as the facilitation work includes, for example, economics, sociology, management theory, and systems theory and auditing to develop innovation capability. To this end, the facilitator requires distinctive consulting skills and specialised methodologies, such as data collection, auditing skills, technology visioning, scenario development, change management, and organisational culture development. There are several reasons an OD practitioner becomes a successful facilitator, according to Barnes and Francis. An OD practitioner is usually seen as neutral in terms of the content of ideas being discussed. He or she facilitates meetings in which innovation topics and activities are discussed and is skilful in the use of process tools, able to assist client groups to make their discussions more inclusive and 
productive and to improve their innovation management process, alert to group process issues that can stifle open discussion, and both aware of the strategic direction in the organisation and positioned to raise the issue of how it is being implemented in any group. Further, the OD practitioner is in a position of trust, with the licence to challenge clients' assumptions; broad in perspective; and able to help clients see how they can move their ideas forward. One concept, developed by Kristiansen and Bloch-Poulsen (2010), is EDIT (Employee Driven Innovation in Teams), where employees from all levels in the organisation are encouraged to contribute to innovation work by forming teams. However, problems such as conflict and lack of performance occurred due to lack of innovation-related knowledge. This led to further research which revealed that an innovation facilitator played a significant important role in innovation work by allowing and maintaining space in discussions among the team members, keeping the meetings effective by ensuring that teams avoided endless discussions, and helping the team members see things from the same perspective (Bloch-Poulsen, 2011).

When it comes to practical work, the facilitator should (Heikkinen et al., 2007; Martin, 2011; Knight and Harland, 2005) promote product and process innovation. However, the facilitator should stay outside the actual development processes, providing possibilities for actions to take place without disturbing the process in any way. Nevertheless, the facilitator may influence the work quite radically in that without the position's existence, the work might not be conducted at all or its operations severely hindered (Heikkinen et al., 2007).

As demonstrated above, a facilitator needs to handle a complex context to stimulate innovation output through innovation teams. In this regard, an increased research focus on required competence is emerging, that is, research on the management of social capabilities to increase innovation output (Vincenzo and Mascia, 2011); on characteristics such as strong brokering skills, social competence, and the ability to cope with uncertain situations (Du Chantenier et al., 2010; Han and Hovav, 2012); and on building trust in the innovation project and among team members (Kadefors, 2003; Maurer, 2010; Smyth et al., 2010). A holistic picture of competence is provided by Illeris (2013) by means of the Competence Flower, which demonstrates 20 different factors that all together constitute competence. In this illustration, the context is illustrated as soil in which the flower is planted. The flower's stem is related to capacities, dispositions, and potentials. Then there are two circles of flower petals. The inner circle consists of a personal profile, knowledge, skills, attitudes, judgements and decisions, a holistic perspective, structural understanding, sociability and collaboration, and autonomy. The outer circle of petals consists of creativity, fantasy, combination ability, flexibility, empathy, intuition, critical perspective, and resistance potential. These factors together become actions in specific situations, which also surrounds the flower's receptacle. In brief, the key elements of competence involve not only intellectual but also emotional capacities, dispositions, and potentials. These capacities and potentials are used in practice through actions where immediate judgements, and decision-making also take place. Further, these actions are made in known and unknown situations. Bozic (2016) has developed the understanding of the Competence Flower even further by suggesting a theoretical framework for innovation competence based on relevant literature and research, in which the four areas of innovation practice, content, intra- and interpersonal characteristics are integrated and related to each other. The centre of Bozic's framework is innovation practice, which consists of idea exploration, idea generation, idea championing, and idea implementation. The model's content consists of definitions of innovation, innovation models, good innovation 
practices, and innovation skills such as questioning, observing, networking, experimenting, and associating. The area of intrapersonal characteristics comprises curiosity, autonomy, flexibility, the ability to perceive, motivation, ambitiousness, creativity, self-confidence, entrepreneurship, and intuition. The area of interpersonal characteristics consists of listening, empathy, sharing, dialogue, improvisation, and feedback. In addition to the model described, the learning aspect of developing competence depends on four types of learning: cumulative, assimilative, accommodative, and transformative. The latter is the most complex level of learning (ibid). Transformative learning, when the knowledge becomes one's own, includes creative learning that is created from reflections in unknown situations and is very important for innovation work (Ellström and Nilsen, 2014).

Based on the seven steps when innovating, as suggested by Milton and Rogers (2013), Räsänen et al. (2015) integrated innovation competence to sort out when specific competence is required. They identified competence refers to individual interpersonal and networking aspects and was categorised into five sub-dimensions, namely creative problem-solving skills, systems thinking, goal orientation, team working, and networking skills. When merging the innovation competences with the innovation process, a theoretical framework was suggested. First, idea screening and idea generation include holistic knowledge and the competence regarding abilities to see new possibilities everywhere and to spread new ideas widely. Second, concept development includes the competence to think independently, listen to others, and communicate to transmit and share knowledge and new ideas in the team. The third step, system design, includes the ability to analyse the relationships among systems, work persistently, and interact and share knowledge with others. The fourth step, detail design, includes competence in interacting and sharing knowledge with others and in understanding details. Fifth, building the system includes competent abilities to take group members' viewpoints and cultural backgrounds into account. The sixth step, testing and validation, includes competent abilities to consider a product from a detailed and holistic perspective. Finally, market launch and delivery include the productive cooperation with professionals and the network from different fields.

The innovation process is usually divided into steps, stages, or phases starting with ideation, in which new ideas are generated, followed by the development of the idea and ending in a market launch. Amabile et al. (1996) divide the process into two parts: a first, creative phase and a second, implementation phase in which the product is developed and launched into the market. Tidd and Bessant (2009) suggest four phases when developing ideas for the market: search for new ideas and innovative opportunities; select ideas to develop and determine what to do further; develop the idea and launch it on the market; and collect the value created. However, the process is not linear, even though the first impression might look that way, but iterative, and loops are taken repeatedly. Besides the innovation processes demonstrated by Milton and Rogers and by Tidd and Bessant, similar innovation processes are suggested by numerous authors (e.g. Baxter, 2002; Farris, 1972; Johnsson, 2009; Trott, 2012). The main differences are how they are more or less practically or theoretically oriented where latter literature suggests an agile approach to innovation work, i.e. to work iterative and flexible to avoid being trapped in gates where valuable time is lost (e.g. Adkins, 2010; Highsmith, 2009; Johnsson, 2009); generally, three phases are common to the innovation processes presented, i.e. an ideation-related phase, execution where the idea is developed and launched on the market, and value harvesting. The practical work when generating ideas is highly abstract and involves many uncertainties, and the 
abstract work continues throughout the selection phases of what ideas to prototype and test for market reactions. As the learning increases based on the work conducted, the level of abstractness decreases to become more and more similar to everyday work (Johnsson, 2014).

To conclude, previous research has identified that innovation teams are recommended for agile innovation work and that a facilitator is suggested to be the link to the ability to practice innovation work (e.g., Andrew and Sirkin, 2008; Howell et al., 2004; Heikkinen, et al., 2007). Prior research regarding the personal characteristics of conducting innovation work has been focusing on the individuals conducting practical innovation work (e.g. Bozic, 2016; KairistoMertanen et al., 2011) or on the innovation driver (Johnsson et al., 2010; Hallgren, 2009). Räsänen et al. (2015) have charted the personal characteristics of students in an innovation process to demonstrate when certain characteristics are needed in accordance with an innovation process. The innovation process itself is not standardised. Although there are similarities among the different variations, the work that is supposed to be conducted and guided through by the facilitator is complex (Barnes and Francis, 2006; Hunter and Cushenbery, 2011). This implies that the facilitator must be able to handle all upcoming uncertainties and complexities. Still, prior research has not yet fully explored the facilitator's required characteristics and presence in ongoing, long-term innovation projects conducted by innovation teams in an industrial context, into which this study will provide new insight.

Based on the introduction and literature review, two questions have emerged: Which characteristics, if any, are required of an innovation facilitator when facilitating innovation teams, and when in relation to the innovation process are the innovation facilitator's characteristics most needed?

\section{Research design}

To gain knowledge about the facilitator's characteristics and presence needed in innovation projects, this study investigated the members of three innovation teams (teams) and their sponsor; Team A consisted of 4 members, Team B of 4 members, and Team $\mathrm{C}$ of 7 members. The teams' only restrictions were to deliver innovative concepts that distinctly demonstrated business opportunities and customer value. In this longitudinal ethnographic research, the researcher also participated as facilitator in the innovation projects. However, the researcher was well aware of that participating research might influence the teams and their performance (Gummesson, 2000) and took actions to prevent bias by discussing this matter with the respondents and through continuous reflections throughout the study.

The teams were all systematically created and prepared through five steps to conduct agile innovation work with the support of the facilitator (Johnsson, 2017). First, the sponsor secured top management and the management's commitment. Second, the sponsor and the facilitator identified an innovation team convener (convener) with the purpose of gathering an innovation team. Third, the facilitator prepared the convener with explicit instructions regarding how to manage agile innovation projects (Johnsson, 2009), how to systematically gather team members on a X-functional basis. Fourth, the convener gathered the innovation team members. Fifth was the innovation project's kick-off, that is, the convener planned and executed a kick-off regarding the idea to develop, during which the team members were introduced to agile innovation work 
and group dynamics. To visualise the innovation project's progress, the innovation process demonstrated by Tidd and Bessant (2009) was chosen, consisting of four phases: searching for ideas, selecting an idea to develop, implementing and launching a developed product (e.g., services or processes) on the market, and capturing the value created through the process.

The facilitator was involved with guidance, advice, and explanations of both forthcoming work in the innovation process and expected group dynamic reactions along the projects. All communication regarding the innovation projects was held with the conveners, who then forwarded the information to the other team members.

Similar to Howell et al.'s (2005) study, which identified innovation championing behaviours, this study was conducted stepwise so as not to influence the participants with the pre-defined characteristics of a facilitator. The data were collected from the team members and the sponsor at the point when the innovation projects had reached the early steps in the implementation phase demonstrated by Tidd and Bessant (2009). This was done in three steps: First, an in-depth interview was conducted that focussed on significantly important characteristics a facilitator should possess, the facilitator's effect on the innovation project, and whether the team members had learned to conduct innovation work at a level where they could conduct a new innovation project by themselves. The interviews were audio-recorded and lasted for approximately 40 minutes each. The reason for choosing to interview in this first step is that interviews make it possible to come close to the respondent and are a valid way to understand someone's perspective (Maxwell, 2013); they are recommended for obtaining information that cannot be observed in surveys (Blessing and Chakrabarti, 2009), as interviews make it possible to explore divergences in the respondents' opinions and descriptions of experiences (Yin, 2013). Next, the applicable sections from the interviews were transcribed, reflectively analysed (Schön, 1991, Yin, 2013), and colour-coded to reveal facilitator characteristics. Forty characteristics were identified and evaluated by the team members and the sponsor to see if the facilitator correlated with the identified characteristics. The evaluators were free to adjust the list of characteristics during this phase. After that, all characteristics were rated in five grades: Crucial, Very important, Important, To some degree important and Unwanted. In the final step, the team members and the sponsor plotted all the characteristics in a time chart. The x-axis demonstrated the time from the preparation of the innovation project through the kick-off to the end of the project, illustrated based on the innovation process by Tidd and Bessant (2009). The y-axis demonstrated the importance of the facilitator's characteristics for the team on a scale of 1 to 7 , where 1 indicated Not important and 7 indicated Very important.

The collected data were analysed by first photo documenting and charting the data, followed by a thematic analysed in accordance with (Boyatzis, 1998) to identify themes and patterns of the characteristics. All the characteristics were found to be important to some extent. Characteristics were highlighted when; $50 \%$ or more of the team members in at least two teams rated characteristics to the same degree and when at least one team member from each team and the sponsor rated one characteristic to the same degree (see Table 1). The plotted characteristics in the time chart were analysed in accordance with the innovation process demonstrated by Tidd and Bessant (2009) to identify in what phase of the innovation process the facilitator's characteristics were most important. 


\subsection{Examples of coding - Interviews}

Quotes from the interviews (below) demonstrate how the questions were asked and the researcher's awareness of his impact on the teams. Significant parts of the answers are highlighted in bold style to visualise examples of the coding, which were used in the first steps of the analyze work. The numbers in brackets indicate the time in the interview where the respondents' start to answer the question asked.

Researcher: "Have you noticed my appearance in the project?"

Sponsor (25.53): "Yes. If you'd ask the convener he would say that it wouldn't be possible to do the work without you because you provide him with confidence in the methodology "Yes, you're supposed to feel a bit worried now. No, you need to iterate and reconsider your choices". That kind of coaching is incredible important together with your e-mails where he can see "yes", which strengthens his self-confidence. I mean the coaching in the methodology and your feedback. Without that it he couldn't manage according to what he says. So, in that sense I think you are present."

Respondent 2 (R2) (46.03): "Yes. You were definitely involved when we had challenges of the commitment aspects. Very present and visible when we kicked things off. You've been involved in meetings throughout, maybe not so much leading and championingbut being there as a support mechanism. So, I would say yes, visible when needed and I think that has been fine for the team."

Researcher: "How do I affect your work according to you?"

Sponsor (28.50): "You represent the methodology they use. I mean, they are conducting the work by themselves but you ensure that they don't jump into conclusions. They think broader than product development only now, which otherwise is the normal way in our company...You coordinate them to see the bigger picture and to not run too fast."

R2 (48.48): "You're affecting our work by providing yourinput when you feel it's needed. So, if we're missing something my expectation is that were you can contribute. If we're bearing off path you can bring us back. If we're not doing something, whatever that may be, my expectation is that you highlight that and challenge the team. If we need to be challenged I expect you to challenge the team."

Researcher: "What personal characteristics do I have that affects the project?"

Sponsor (33.13): "You're good at strengthen the convener's self-confidence, selfesteem and courage by your e-mails for example and your coaching skills. You steer them towards things to do when needed, and you make them believe that it's the right thing to do by encouraging them and strengthen their self-esteem. I could never do what you do. I'm too inpatient and dominant. Even though I'd read all papers and understood everything I would have taken too much space. You're a much better listener, patient. I wonder if they realise how good you are on this and how much you really know about this. I don't want to change this, because I believe this is one of the keys to why this works. You're so incredible good, you let them shine. You're there, tweaking and adjusting small things that lifts them up." 
R2 (55.15): "Yes. You're knowledge in your expertise which affect the team in a positive way, your feedback whether it's positive or negative is constructive. That kind of input affect the team. And feedback, if we're doing well it's good to know that we are at least heading in the right position and I get that from you. Sharing what you do, how you do, helping to drive those two X-functional teams helped to build the credibility to the process to the team. So I think there a lot of positive aspects to who you and what your characteristics are and what you bring to the table."

Researcher: Would you have come this far without my participation?

Sponsor (34.58): "No. What do you think after what I just said? I don't think they would."

R2 (56.23): "No, we would not have come this far."

Researcher: "If I was replaced for somebody else, what would that person need to get the team to perform?"

Sponsor (43.13): "The facilitating role is supposed to be done internally in the future. And they need the entrepreneurial-management-insight, humbleness to the team, maturity and ability to listen and have patient let it wait for another week. There's a internal need for competence, attitude and leadership regarding this."

R2 (57.52): "I would say trust in the team, encouragement for the team, background, communication. If the team is starting to derail, being able to highlight that "you're off track, and my job is to steer you back" having the force in the communication, expertise to bring the team back around, competence. I guess I come back to the knowledge of the process to steer us to ensure us that it's the right direction. This could easily come off track. So I think somebody familiar with the process is needed."

Researcher: "If a new high performing innovation team is created, does it need a facilitator or is written instructions and tools enough?"

Sponsor (36.11): "No, it won't work. If you'd quit today I'd try to keep the methodology alive myself. I'd employ a physical person that could observe and coach them..."

R2 (59.53): "I'm going to say initially no. But, I think through time as more and more people are involved in high performing innovation team projects and understand and learn the process. Then yes. Maybe."

Researcher: Something you'd like to add or something you wanted to say that I didn't ask you about?

Sponsor (41.36): No. Nothing that I can think of, except for that I've been bragging so much about our work that we are going to present it at the next coming conference.

R2 (1.08.10): "I appreciate your feedback, it feels right. I can not compare to anything but we seem to making progress. We seem to be in line with what we should be doing at this time in the process. 


\subsection{Examples of coding - Questionnaires}

The questionnaires regarding the respondent's and the sponsor's evaluation of the facilitator's characteristics were charted and analysed in three steps; first by importance (Figure 1), followed by evaluating if the facilitator possessed the characteristics (Figure 2), and finally plotted in a time chart (Figure 3). The sponsor's data were systematically compared to the teams' data in average to identify deviation and similarities.

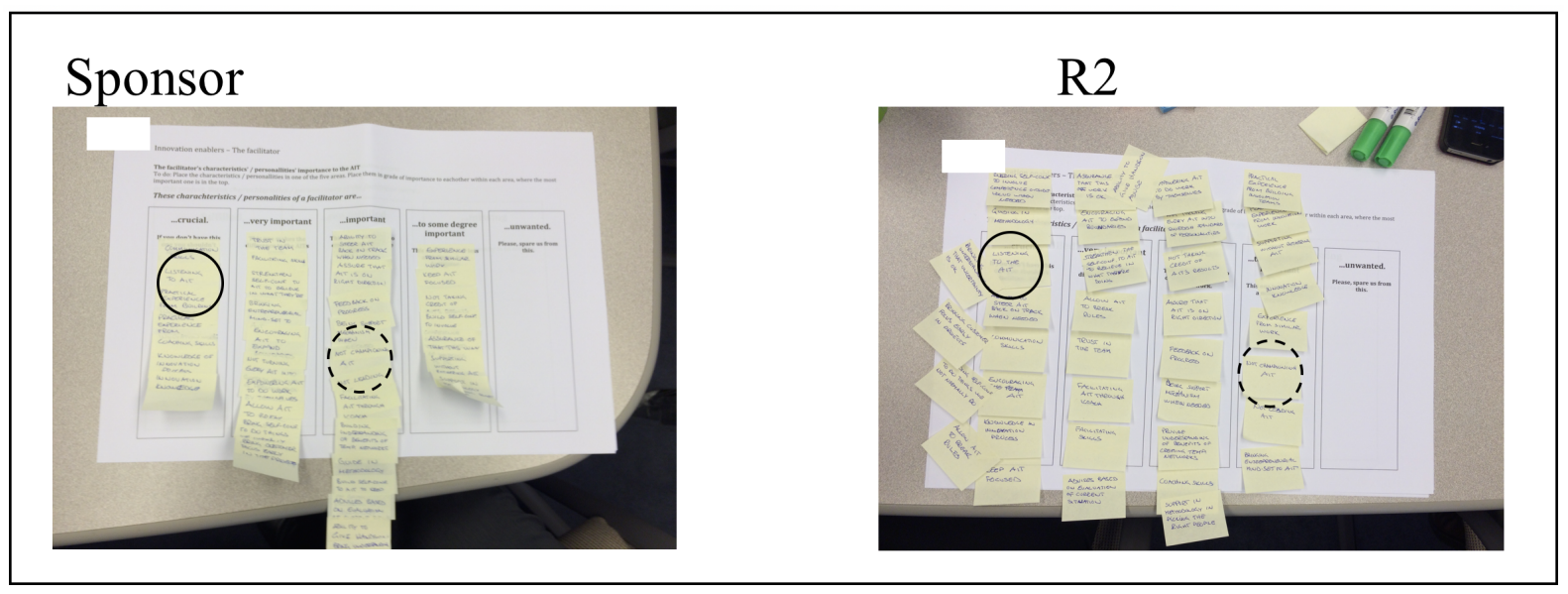

Fig. 1. The figure demonstrates the rated characteristics by the sponsor and Respondent 2

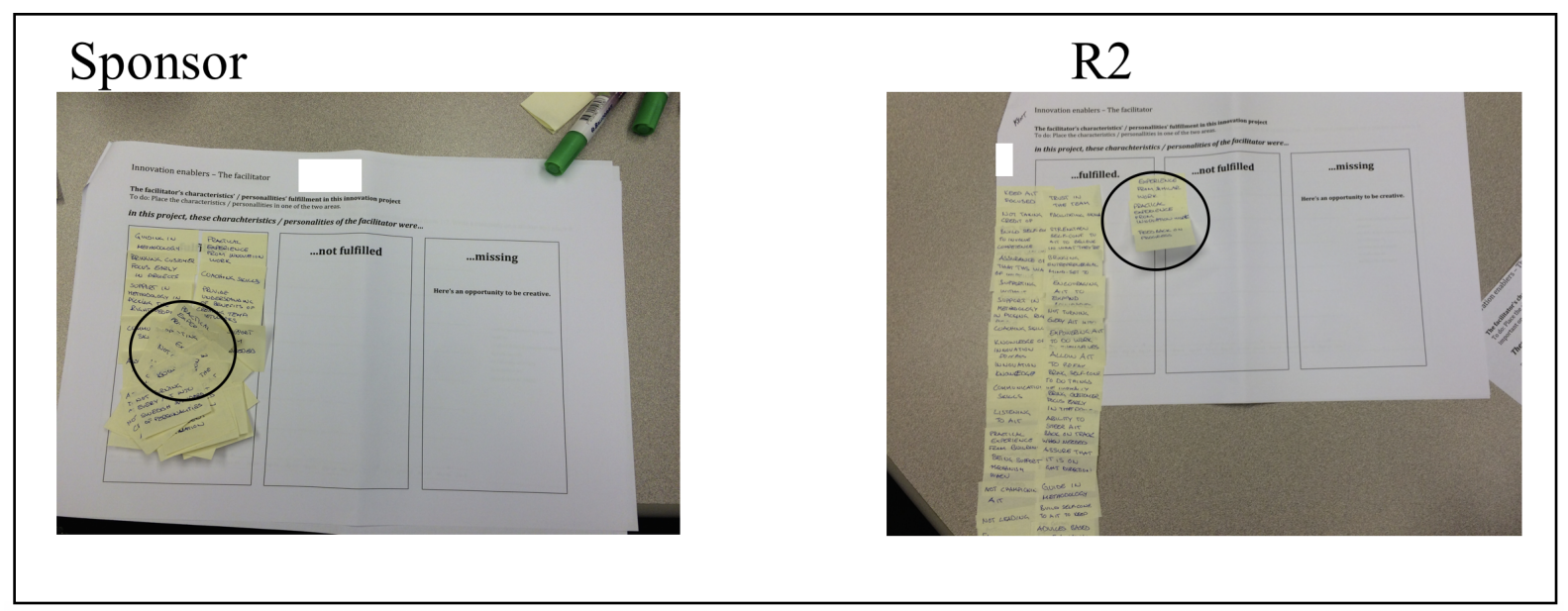

Fig. 2. The figure demonstrates how the facilitator's characteristics correlate to the identified characteristics according to the Respondent and Respondent 2. 


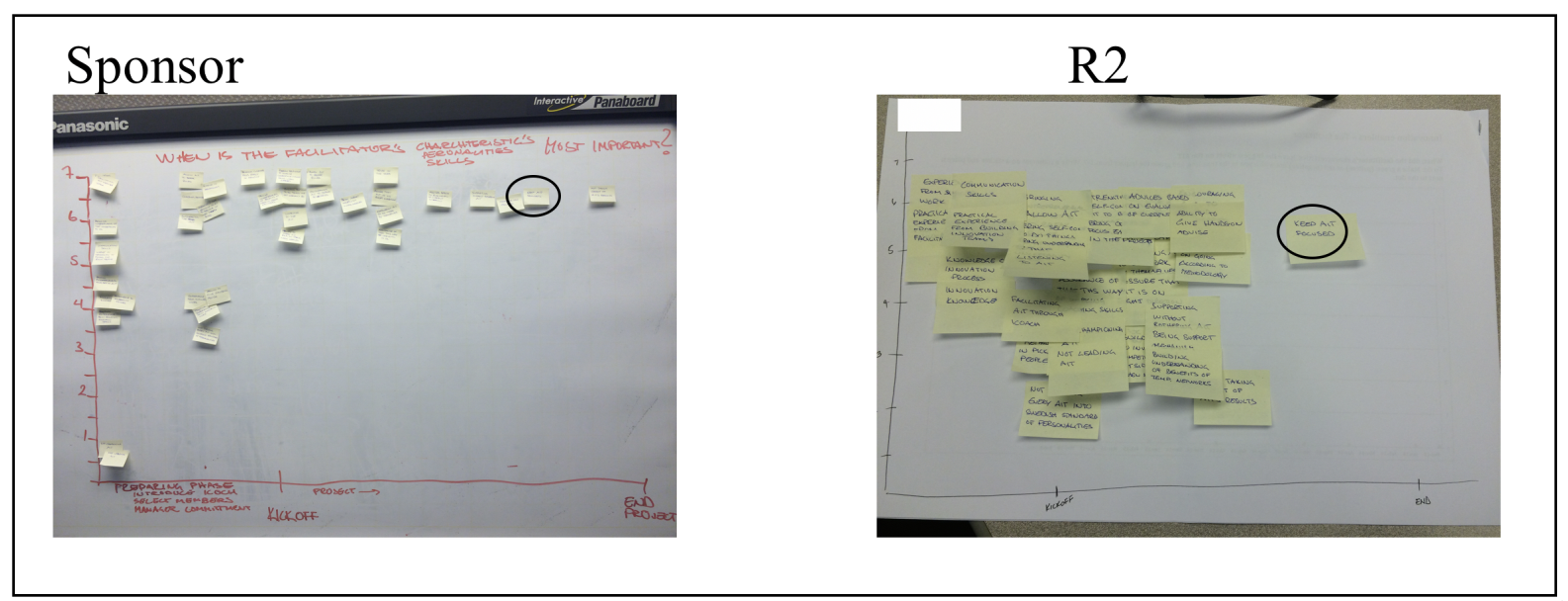

Fig. 3. The figure demonstrates the plotted characteristics in the time chart by the sponsor and Respondent 2.

\section{Results}

The interviews revealed forty characteristics that a facilitator should possess (see Table 1, column: Characteristic). All respondents found the facilitator's characteristics important to some extent, but the level of importance varied individually. Both similarities and deviations were identified in how the sponsor and the team members assessed the importance of the facilitator's characteristics during an innovation project.

The team members and the sponsor were fully aligned in their assessment of the characteristics' importance in three areas. "Strengthen team's confidence in what they are doing" was considered to be very important; "Advice based on the evaluation of the current situation" and "Feedback on progress" were considered to be important. Also aligned to some degree were the characteristics in the following three areas: "Listening to the team" and "Knowledge of the innovation process" were considered to be crucial by the sponsor and by at least two of the teams' members; "Assure that the team is on the right track" was considered to be important by the sponsor and at least one team member in each team.

Minor deviations were identified regarding ten characteristics. "Trust in the team" was considered to be crucial by the team members and very important by the sponsor; "Develop understanding that uncertainty is OK", "Build self-confidence to do things we do not normally do", and "Allow the team to break rules" were considered to be very important by the team members, and the sponsor considered these characteristics to be crucial. "Supporting without bothering the team", "Coaching skills", and "Challenge the team when needed" were considered to be very important by the team members, and the sponsor considered these characteristics to be important. "Facilitating through convener" and "Ability to give hands-on advice" were considered to be important by the team members, and the sponsor considered these characteristics to be very important. "Build team confidence to continue according to methodology" was considered to be important by the team members and to some degree important by the sponsor.

Significant deviations were identified for five characteristics. "Not championing the team" was 
considered to be crucial by at least one respondent in each team and to some degree important by the sponsor. "Encouraging the team to expand boundaries", "Support in methodology of picking the right people", "Innovation knowledge", and "Practical experience from building innovation teams" were considered to be important or very important by the team members and to some degree important by the sponsor. From the teams' perspective, the characteristics relates to the facilitator's ability to build trust in the team by being able to demonstrate his or her competence. The empty boxes in Table 1 do not demonstrate that the characteristics are unimportant but rather indicate that the respondents' assessment of their importance varies significantly.

Regarding whether the facilitator possessed the identified characteristics or not, the sponsor and all team members but four assessed that the facilitator possessed all the identified characteristics (see Table 1). The four team members explained their responses from three perspectives: first, the team already possessed that knowledge; second, they did not know about work that they were not part of; and third, this was an ongoing research project in which these characteristics were tested and evaluated. One of the team members, who also acted as convener felt that the facilitator was disturbing the team's work from time to time.

Table 1 demonstrates the facilitator's characteristics and how the respondents assessed their importance. The table also demonstrates identified themes and characteristics that were not fulfilled according to the respondent(s).

Table 1. The importance of a facilitator's characteristics

\begin{tabular}{|c|c|c|c|c|c|}
\hline No & $\begin{array}{l}\text { Characteristics } \\
\text { (In alphabetical } \\
\text { order) }\end{array}$ & $\begin{array}{l}\text { Team } \\
\text { members } \\
(50 \% \text { or more } \\
\text { of team } \\
\text { members in } \\
\text { at least } 50 \% \\
\text { of the teams) }\end{array}$ & $\begin{array}{l}\text { team } \\
\text { members } \\
\text { (At least } \\
\text { one team } \\
\text { member in } \\
\text { each team.) }\end{array}$ & 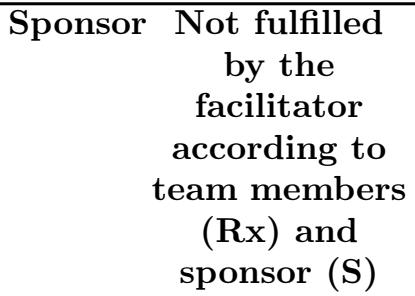 & Theme \\
\hline 1 & $\begin{array}{l}\text { Ability to give } \\
\text { hands-on advice. }\end{array}$ & Important & Important & $\begin{array}{l}\text { Very } \\
\text { impor- } \\
\text { tant }\end{array}$ & $\begin{array}{l}\text { Knowledge } \\
\text { manage- } \\
\text { ment }\end{array}$ \\
\hline 2 & $\begin{array}{l}\text { Ability to steer the } \\
\text { team back on track } \\
\text { when needed. }\end{array}$ & $\begin{array}{l}\text { Very } \\
\text { important }\end{array}$ & $\begin{array}{l}\text { Very } \\
\text { important }\end{array}$ & Crucial & $\begin{array}{l}\text { Knowledge } \\
\text { manage- } \\
\text { ment }\end{array}$ \\
\hline 3 & $\begin{array}{l}\text { Advises based on } \\
\text { evaluation of current } \\
\text { situation. }\end{array}$ & $\begin{array}{l}\text { Very } \\
\text { important }\end{array}$ & $\begin{array}{l}\text { Very } \\
\text { important }\end{array}$ & $\begin{array}{l}\text { Very } \\
\text { impor- } \\
\text { tant }\end{array}$ & $\begin{array}{l}\text { Knowledge } \\
\text { manage- } \\
\text { ment }\end{array}$ \\
\hline 4 & $\begin{array}{l}\text { Allow the team to } \\
\text { break rules. }\end{array}$ & $\begin{array}{l}\text { Very } \\
\text { important }\end{array}$ & & Crucial & $\begin{array}{l}\text { Knowledge } \\
\text { manage- } \\
\text { ment }\end{array}$ \\
\hline 5 & $\begin{array}{l}\text { Assurance of that } \\
\text { this way of working } \\
\text { is OK. }\end{array}$ & & & $\begin{array}{l}\text { Very } \\
\text { impor- } \\
\text { tant }\end{array}$ & $\begin{array}{l}\text { Knowledge } \\
\text { transfer }\end{array}$ \\
\hline
\end{tabular}




\begin{tabular}{|c|c|c|c|c|c|}
\hline No & $\begin{array}{l}\text { Characteristics } \\
\text { (In alphabetical } \\
\text { order) }\end{array}$ & $\begin{array}{l}\text { Team } \\
\text { members } \\
(50 \% \text { or more } \\
\text { of team } \\
\text { members in } \\
\text { at least } 50 \% \\
\text { of the teams) }\end{array}$ & $\begin{array}{l}\text { team } \\
\text { members } \\
\text { (At least } \\
\text { one team } \\
\text { member in } \\
\text { each team.) }\end{array}$ & 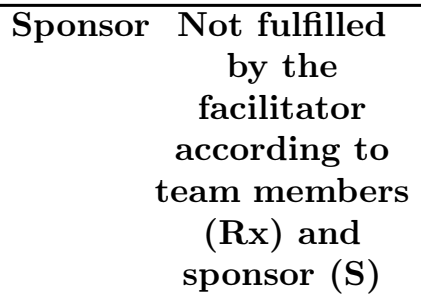 & Theme \\
\hline 6 & $\begin{array}{l}\text { Assure that the team } \\
\text { is on right direction. }\end{array}$ & & Important & Important & $\begin{array}{l}\text { Knowledge } \\
\text { transfer }\end{array}$ \\
\hline 7 & $\begin{array}{l}\text { Being support } \\
\text { mechanism when } \\
\text { needed. }\end{array}$ & & & Important & $\begin{array}{l}\text { Knowledge } \\
\text { manage- } \\
\text { ment }\end{array}$ \\
\hline 8 & $\begin{array}{l}\text { Bring customer focus } \\
\text { early in project. }\end{array}$ & Important & & Crucial & $\begin{array}{l}\text { Knowledge } \\
\text { transfer }\end{array}$ \\
\hline 9 & $\begin{array}{l}\text { Bring } \\
\text { entrepreneurial } \\
\text { mind-set into the } \\
\text { team. }\end{array}$ & & Crucial & $\begin{array}{l}\text { To } \\
\text { some } \\
\text { degree } \\
\text { impor- } \\
\text { tant }\end{array}$ & $\begin{array}{l}\text { Knowledge } \\
\text { transfer }\end{array}$ \\
\hline 10 & $\begin{array}{l}\text { Bring understanding } \\
\text { of that uncertainty } \\
\text { is OK. }\end{array}$ & $\begin{array}{l}\text { Very } \\
\text { important }\end{array}$ & $\begin{array}{l}\text { Very } \\
\text { important }\end{array}$ & Crucial & $\begin{array}{l}\text { Knowledge } \\
\text { transfer }\end{array}$ \\
\hline 11 & $\begin{array}{l}\text { Build self-confidence } \\
\text { to involve } \\
\text { competence outside } \\
\text { the Company when } \\
\text { needed. }\end{array}$ & & Important & R3, R10 & $\begin{array}{l}\text { Knowledge } \\
\text { transfer }\end{array}$ \\
\hline 12 & $\begin{array}{l}\text { Build self-confidence } \\
\text { to the team to keep } \\
\text { on going according } \\
\text { to methodology. }\end{array}$ & Important & Important & $\begin{array}{l}\text { To } \\
\text { some } \\
\text { degree } \\
\text { impor- } \\
\text { tant }\end{array}$ & $\begin{array}{l}\text { Knowledge } \\
\text { transfer }\end{array}$ \\
\hline 13 & $\begin{array}{l}\text { Build self-confident } \\
\text { to do things we not } \\
\text { normally do. }\end{array}$ & $\begin{array}{l}\text { Very } \\
\text { important }\end{array}$ & & Crucial & $\begin{array}{l}\text { Knowledge } \\
\text { transfer }\end{array}$ \\
\hline 14 & $\begin{array}{l}\text { Challenge the team } \\
\text { when needed. }\end{array}$ & & $\begin{array}{l}\text { Very } \\
\text { important }\end{array}$ & Important & $\begin{array}{l}\text { Knowledge } \\
\text { manage- } \\
\text { ment }\end{array}$ \\
\hline 15 & Coaching skills. & $\begin{array}{l}\text { Very } \\
\text { important }\end{array}$ & & Important & $\begin{array}{l}\text { Knowledge } \\
\text { manage- } \\
\text { ment }\end{array}$ \\
\hline 16 & $\begin{array}{l}\text { Communication } \\
\text { skills. }\end{array}$ & & & Crucial & $\begin{array}{l}\text { Knowledge } \\
\text { manage- } \\
\text { ment }\end{array}$ \\
\hline
\end{tabular}




\begin{tabular}{|c|c|c|c|c|c|}
\hline No & $\begin{array}{l}\text { Characteristics } \\
\text { (In alphabetical } \\
\text { order) }\end{array}$ & $\begin{array}{l}\text { Team } \\
\text { members } \\
(50 \% \text { or more } \\
\text { of team } \\
\text { members in } \\
\text { at least } 50 \% \\
\text { of the teams) }\end{array}$ & $\begin{array}{l}\text { team } \\
\text { members } \\
\text { (At least } \\
\text { one team } \\
\text { member in } \\
\text { each team.) }\end{array}$ & 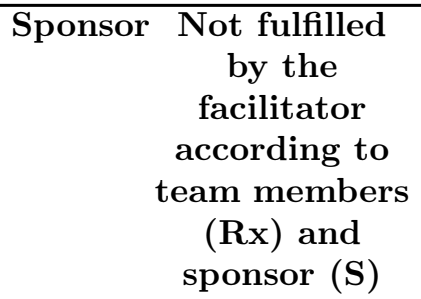 & Theme \\
\hline 17 & $\begin{array}{l}\text { Empowering the } \\
\text { team to do work by } \\
\text { themselves. }\end{array}$ & & & Important & $\begin{array}{l}\text { Knowledge } \\
\text { manage- } \\
\text { ment }\end{array}$ \\
\hline 18 & $\begin{array}{l}\text { Encouraging the } \\
\text { team to expand } \\
\text { boundaries. }\end{array}$ & Important & $\begin{array}{l}\text { Important, } \\
\text { Very } \\
\text { important }\end{array}$ & $\begin{array}{l}\text { To } \\
\text { some } \\
\text { degree } \\
\text { impor- } \\
\text { tant }\end{array}$ & $\begin{array}{l}\text { Knowledge } \\
\text { transfer }\end{array}$ \\
\hline 19 & $\begin{array}{l}\text { Encouraging the } \\
\text { team. }\end{array}$ & & & Crucial & $\begin{array}{l}\text { Knowledge } \\
\text { manage- } \\
\text { ment }\end{array}$ \\
\hline 20 & $\begin{array}{l}\text { Experience from } \\
\text { similar work. }\end{array}$ & & & $\begin{array}{l}\text { To } \\
\text { some } \\
\text { degree } \\
\text { impor- } \\
\text { tant }\end{array}$ & $\begin{array}{l}\text { Innovation } \\
\text { knowledge }\end{array}$ \\
\hline 21 & Facilitating skills. & & & $\begin{array}{l}\text { Very } \\
\text { impor- } \\
\text { tant }\end{array}$ & $\begin{array}{l}\text { Knowledge } \\
\text { manage- } \\
\text { ment }\end{array}$ \\
\hline 22 & $\begin{array}{l}\text { Facilitating through } \\
\text { convener }\end{array}$ & Important & & $\begin{array}{l}\text { Very } \\
\text { impor- } \\
\text { tant }\end{array}$ & $\begin{array}{l}\text { Knowledge } \\
\text { manage- } \\
\text { ment }\end{array}$ \\
\hline 23 & $\begin{array}{l}\text { Feedback on } \\
\text { progress. }\end{array}$ & Important & Important & Important & $\begin{array}{l}\text { Knowledge } \\
\text { manage- } \\
\text { ment }\end{array}$ \\
\hline 24 & $\begin{array}{l}\text { Guiding in } \\
\text { methodology. }\end{array}$ & & & Crucial & $\begin{array}{l}\text { Knowledge } \\
\text { transfer }\end{array}$ \\
\hline 25 & $\begin{array}{l}\text { Highlight when the } \\
\text { team is off track. }\end{array}$ & & & Important & $\begin{array}{l}\text { Knowledge } \\
\text { manage- } \\
\text { ment }\end{array}$ \\
\hline 26 & $\begin{array}{l}\text { Innovation } \\
\text { knowledge. }\end{array}$ & $\begin{array}{l}\text { Very } \\
\text { important }\end{array}$ & $\begin{array}{l}\text { Very } \\
\text { important }\end{array}$ & $\begin{array}{l}\text { To } \\
\text { some } \\
\text { degree } \\
\text { impor- } \\
\text { tant }\end{array}$ & $\begin{array}{l}\text { Innovation } \\
\text { knowledge }\end{array}$ \\
\hline 27 & $\begin{array}{l}\text { Keep the team } \\
\text { focused. }\end{array}$ & & & $\begin{array}{l}\text { To } \\
\text { some } \\
\text { degree } \\
\text { impor- } \\
\text { tant }\end{array}$ & $\begin{array}{l}\text { Knowledge } \\
\text { manage- } \\
\text { ment }\end{array}$ \\
\hline
\end{tabular}




\begin{tabular}{|c|c|c|c|c|c|}
\hline No & $\begin{array}{l}\text { Characteristics } \\
\text { (In alphabetical } \\
\text { order) }\end{array}$ & $\begin{array}{l}\text { Team } \\
\text { members } \\
(50 \% \text { or more } \\
\text { of team } \\
\text { members in } \\
\text { at least } 50 \% \\
\text { of the teams) }\end{array}$ & $\begin{array}{l}\text { team } \\
\text { members } \\
\text { (At least } \\
\text { one team } \\
\text { member in } \\
\text { each team.) }\end{array}$ & $\begin{array}{c}\text { Sponsor } \\
\text { Not fulfilled } \\
\text { by the } \\
\text { facilitator } \\
\text { according to } \\
\text { team members } \\
(\mathrm{Rx}) \text { and } \\
\text { sponsor }(\mathrm{S})\end{array}$ & Theme \\
\hline 28 & $\begin{array}{l}\text { Knowledge of } \\
\text { innovation process. }\end{array}$ & Important & Crucial & Crucial & $\begin{array}{l}\text { Innovation } \\
\text { knowledge }\end{array}$ \\
\hline 29 & $\begin{array}{l}\text { Listening to the } \\
\text { team. }\end{array}$ & Crucial & $\begin{array}{l}\text { Very } \\
\text { important }\end{array}$ & Crucial & $\begin{array}{l}\text { Knowledge } \\
\text { manage- } \\
\text { ment }\end{array}$ \\
\hline 30 & $\begin{array}{l}\text { Not championing the } \\
\text { team. }\end{array}$ & & Crucial & $\begin{array}{l}\text { To } \\
\text { some } \\
\text { degree } \\
\text { impor- } \\
\text { tant }\end{array}$ & $\begin{array}{l}\text { Knowledge } \\
\text { manage- } \\
\text { ment }\end{array}$ \\
\hline 31 & $\begin{array}{l}\text { Not leading the } \\
\text { team. }\end{array}$ & Important & & $\begin{array}{l}\text { To } \\
\text { some } \\
\text { degree } \\
\text { impor- } \\
\text { tant }\end{array}$ & $\begin{array}{l}\text { Knowledge } \\
\text { manage- } \\
\text { ment }\end{array}$ \\
\hline 32 & $\begin{array}{l}\text { Not taking credit of } \\
\text { the team's results. }\end{array}$ & Important & Important & Important & $\begin{array}{l}\text { Knowledge } \\
\text { manage- } \\
\text { ment }\end{array}$ \\
\hline 33 & $\begin{array}{l}\text { Not turning every } \\
\text { team into Swedish } \\
\text { standard of } \\
\text { personalities. }\end{array}$ & & & Important & $\begin{array}{l}\text { Knowledge } \\
\text { manage- } \\
\text { ment }\end{array}$ \\
\hline 34 & $\begin{array}{l}\text { Practical experience } \\
\text { from building } \\
\text { innovation teams. }\end{array}$ & & $\begin{array}{l}\text { Very } \\
\text { important }\end{array}$ & $\begin{array}{l}\text { To } \\
\text { some } \\
\text { degree } \\
\text { impor- } \\
\text { tant }\end{array}$ & $\begin{array}{l}\text { Innovation } \\
\text { knowledge }\end{array}$ \\
\hline 35 & $\begin{array}{l}\text { Practical experience } \\
\text { from innovation } \\
\text { work. }\end{array}$ & Crucial & Crucial & $\begin{array}{l}\text { To } \\
\text { some } \\
\text { degree } \\
\text { impor- } \\
\text { tant }\end{array}$ & $\begin{array}{l}\text { Innovation } \\
\text { knowledge }\end{array}$ \\
\hline 36 & $\begin{array}{l}\text { Provide } \\
\text { understanding of } \\
\text { benefits of creating } \\
\text { temporary networks. }\end{array}$ & & & Important & $\begin{array}{l}\text { Knowledge } \\
\text { transfer }\end{array}$ \\
\hline 37 & $\begin{array}{l}\text { Strengthen the } \\
\text { self-confident to the } \\
\text { team to believe in } \\
\text { what they're doing. }\end{array}$ & $\begin{array}{l}\text { Very } \\
\text { important }\end{array}$ & $\begin{array}{l}\text { Very } \\
\text { important }\end{array}$ & $\begin{array}{l}\text { Very } \\
\text { impor- } \\
\text { tant }\end{array}$ & $\begin{array}{l}\text { Knowledge } \\
\text { transfer }\end{array}$ \\
\hline
\end{tabular}




\begin{tabular}{|c|c|c|c|c|c|}
\hline No & $\begin{array}{l}\text { Characteristics } \\
\text { (In alphabetical } \\
\text { order) }\end{array}$ & $\begin{array}{l}\text { Team } \\
\text { members } \\
\text { (50\% or more } \\
\text { of team } \\
\text { members in } \\
\text { at least } 50 \% \\
\text { of the teams) }\end{array}$ & $\begin{array}{l}\text { team } \\
\text { members } \\
\text { (At least } \\
\text { one team } \\
\text { member in } \\
\text { each team.) }\end{array}$ & $\begin{array}{c}\text { Sponsor } \\
\text { Not fulfilled } \\
\text { by the } \\
\text { facilitator } \\
\text { according to } \\
\text { team members } \\
(\mathrm{Rx}) \text { and } \\
\text { sponsor }(\mathrm{S})\end{array}$ & Theme \\
\hline 38 & $\begin{array}{l}\text { Support in } \\
\text { methodology in } \\
\text { picking the right } \\
\text { people. }\end{array}$ & $\begin{array}{l}\text { Very } \\
\text { important }\end{array}$ & & $\begin{array}{l}\text { To } \\
\text { some } \\
\text { degree } \\
\text { impor- } \\
\text { tant }\end{array}$ & $\begin{array}{l}\text { Knowledge } \\
\text { transfer }\end{array}$ \\
\hline 39 & $\begin{array}{l}\text { Supporting without } \\
\text { bothering the team. }\end{array}$ & $\begin{array}{l}\text { Very } \\
\text { important }\end{array}$ & & Important & $\begin{array}{l}\text { Knowledge } \\
\text { manage- } \\
\text { ment }\end{array}$ \\
\hline 40 & Trust in the team. & Crucial & & $\begin{array}{l}\text { Very } \\
\text { impor- } \\
\text { tant }\end{array}$ & $\begin{array}{l}\text { Knowledge } \\
\text { manage- } \\
\text { ment }\end{array}$ \\
\hline
\end{tabular}

The characteristics were plotted in a time chart by the team members (Figure 4) and the sponsor (Figure 5). The results demonstrate that the facilitator's presence and practical advice were most important in the pre-phase and the first two phases of the innovation process. Later, in the early steps of the implementation phase, it became more important to have access to the facilitator when needed, similar to back-office support. The plotted characteristics in the time chart demonstrate that the teams generally assessed all the identified characteristics as important to some degree except for two characteristics in the first phase: "Not turning every team into Swedish standard personalities" and "Provide understanding of the benefits of creating temporary networks". These findings were explained by the fact that two of the teams were Swedish, which made them biased, and the network-related item was quite obvious, according to the team members. Similarly to the team members, the sponsor also assessed all the identified characteristics as important to some degree except for "Not turning every team into Swedish standard personalities". The difference, however, is that Swedish employees within this global company tend to be less hierarchic and more entrepreneurial, which the sponsor appreciated in this work. The sponsor also assessed "Not leading the team" and "Not championing the team" as not important at all. 


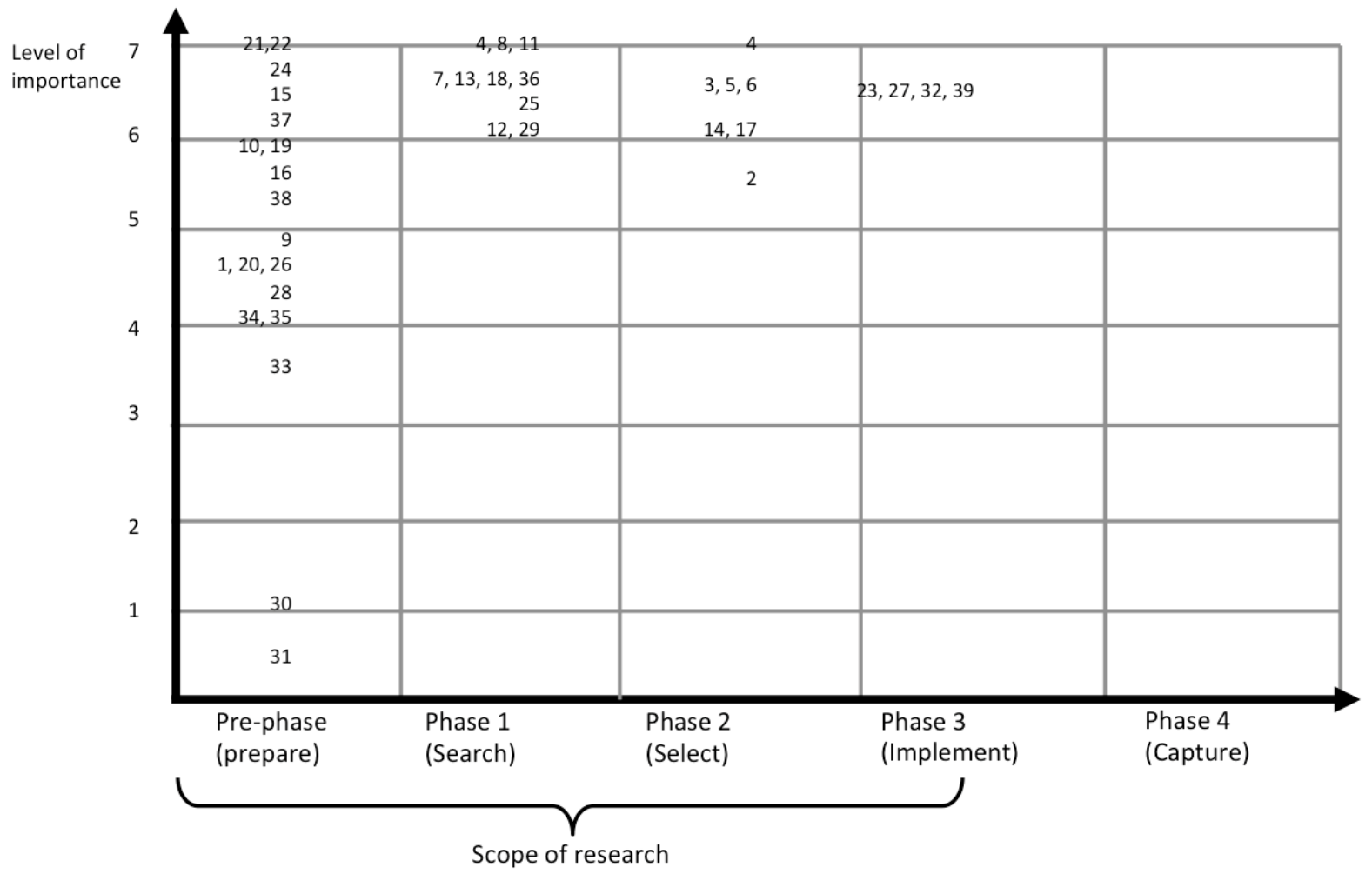

Fig. 4. The figure demonstrates when the facilitator's characteristics are most important in innovation projects, according to the sponsor. 


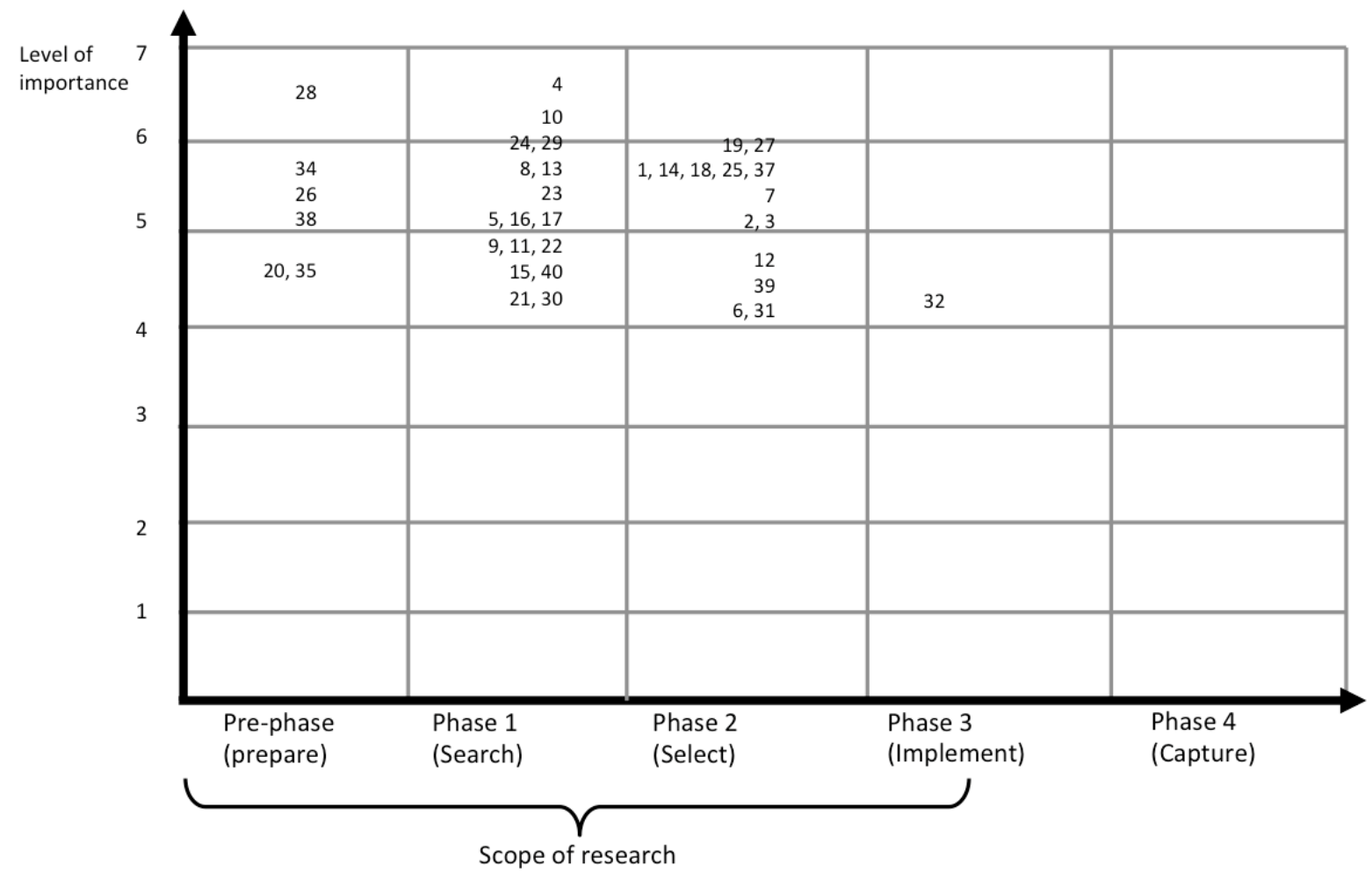

Fig. 5. The figure demonstrates when the facilitator's characteristics are most important in innovation projects, according to the teams on average.

Considering the sponsor's assessments of the characteristics' importance compared to the team members' assessments on average, the deviations are not significant (Table 2). Three of the characteristics were rated the same, with a difference of two decimals: "Develop understanding that uncertainty is OK", "Listen to the team", and "Experience from similar work". The biggest deviation in rating was identified for two characteristics, where the teams rated "Not leading the team" and "Not championing" to be important, but the sponsor rated these characteristics as not important.

The biggest deviations between the sponsor and the teams were related to when in the innovation process the characteristics were important. In general, the sponsor rated the facilitator's characteristics as more important than the teams did (Table 3). The sponsor assessed 21 characteristics, and the teams assessed 6 characteristics as important in the pre-phase. One explanation was identified from the interviews: Team members commented that they did not know what was going on before the kick-off and were unaware of the ongoing communication between the facilitator and the convener between team meetings; they therefore found it difficult to relate to that work. The sponsor, on the other hand, was very well informed regarding the activities in the pre-phase, the teams' work and progress, and the ongoing communication between the convener and the facilitator; in this way, they had a more holistic view than the teams. 
Table 2. The table demonstrates how important the facilitator's characteristics are according to the innovation teams and the sponsor.

\begin{tabular}{|c|c|c|c|}
\hline & & $\begin{array}{l}\text { Innovation team members } \\
\text { [Average] }\end{array}$ & Sponsor \\
\hline No & $\begin{array}{l}\text { Characteristics (In alphabetical } \\
\text { order) }\end{array}$ & $\begin{array}{l}\text { (Grade of importance } 1-7 \text { ) } \\
1=\text { not imp. } 7=\text { very imp. } \\
\text { (Low and High indicates } \\
\text { the lowest and highest rate) }\end{array}$ & $\begin{array}{c}\text { (Grade of importance } \\
\begin{array}{c}1-7) 1=\text { not imp. } \\
7=\text { very imp. }\end{array}\end{array}$ \\
\hline 1 & Ability to give hands-on advice. & 5.5 (Low: 1.0 - High: 6.5) & 4.5 \\
\hline 2 & $\begin{array}{l}\text { Ability to steer the team back on } \\
\text { track when needed. }\end{array}$ & 4.9 (Low: 3.0 - High: 7.0) & 5.75 \\
\hline 3 & $\begin{array}{l}\text { Advises based on evaluation of } \\
\text { current situation. }\end{array}$ & 4.9 (Low: 3.0 - High: 7.0) & 6.5 \\
\hline 4 & Allow the team to break rules. & 6.5 (Low: 2.5 - High: 7.0) & 7.0 \\
\hline 5 & $\begin{array}{l}\text { Assurance of that this way of } \\
\text { working is OK. }\end{array}$ & 5.0 (Low: 3.0 -High: 7.0) & 6.5 \\
\hline 6 & $\begin{array}{l}\text { Assure that the team is on right } \\
\text { direction. }\end{array}$ & 4.1 (Low: 2.0 - High: 7.0) & 6.5 \\
\hline 7 & $\begin{array}{l}\text { Being support mechanism when } \\
\text { needed. }\end{array}$ & 5.3 (Low: 3.0 - High: 7.0) & 6.25 \\
\hline 8 & $\begin{array}{l}\text { Bring customer focus early in } \\
\text { project. }\end{array}$ & 5.5 (Low: 3.5 - High: 7.0) & 7.0 \\
\hline 9 & $\begin{array}{l}\text { Bring entrepreneurial mind-set into } \\
\text { the team. }\end{array}$ & 4.9 (Low: 1.5 - High: 7.0) & 4.75 \\
\hline 10 & $\begin{array}{l}\text { Bring understanding of that } \\
\text { uncertainty is OK. }\end{array}$ & 5.9 (Low: 5.5 - High: 6.5) & 6.0 \\
\hline 11 & $\begin{array}{l}\text { Build self-confidence to involve } \\
\text { competence outside the Company } \\
\text { when needed. }\end{array}$ & 4.9 (Low: 2.0 - High: 7.0) & 7.0 \\
\hline 12 & $\begin{array}{l}\text { Build self-confidence to the team to } \\
\text { keep on going according to } \\
\text { methodology. }\end{array}$ & 4.6 (Low: 3.0 - High: 6.0) & 6.0 \\
\hline 13 & $\begin{array}{l}\text { Build self-confident to do things we } \\
\text { not normally do. }\end{array}$ & 5.3 (Low: 4.5 - High: 6.5) & 6.5 \\
\hline 14 & Challenge the team when needed. & 5.5 (Low: 3.5 - High: 7.0) & 6.0 \\
\hline 15 & Coaching skills. & 4.7 (Low: 2.0 - High: 7.0) & 6.5 \\
\hline 16 & Communication skills. & 5.0 (Low: 3.0 - High: 7.0) & 6.5 \\
\hline 17 & $\begin{array}{l}\text { Empowering the team to do work by } \\
\text { themselves. }\end{array}$ & 5.1 (Low: 3.5 - High: 7.0) & 6.0 \\
\hline 18 & $\begin{array}{l}\text { Encouraging the team to expand } \\
\text { boundaries. }\end{array}$ & 5.5 (Low: 4.0 - High: 6.5) & 6.5 \\
\hline 19 & Encouraging the team. & 5.8 (Low: 3.5 - High: 7.0) & 6.0 \\
\hline 20 & Experience from similar work. & 4.6 (Low: 1.0 - High: 6.0) & 4.5 \\
\hline 21 & Facilitating skills. & 4.2 (Low: 2.5 - High: 7.0) & 7.0 \\
\hline 22 & Facilitating through convener & 4.8 (Low: 2.0 - High: 6.0) & 7.0 \\
\hline 23 & Feedback on progress. & 5.1 (Low: 4.0 - High: 6.0) & 6.5 \\
\hline 24 & Guiding in methodology. & 5.8 (Low: 1.5 - High: 7.0) & 6.75 \\
\hline 25 & Highlight when the team is off track. & 5.5 (Low: 5.5 - High: 7.0) & 6.5 \\
\hline
\end{tabular}




\begin{tabular}{|c|c|c|c|}
\hline & & $\begin{array}{l}\text { Innovation team members } \\
\text { [Average] }\end{array}$ & Sponsor \\
\hline No & $\begin{array}{l}\text { Characteristics (In alphabetical } \\
\text { order) }\end{array}$ & $\begin{array}{l}\text { (Grade of importance } 1-7 \text { ) } \\
1=\text { not imp. } 7=\text { very imp. } \\
\text { (Low and High indicates } \\
\text { the lowest and highest rate) }\end{array}$ & $\begin{array}{l}\text { (Grade of importance } \\
\begin{array}{c}1-7) 1=\text { not imp. } \\
7=\text { very imp. }\end{array}\end{array}$ \\
\hline 26 & Innovation knowledge. & 5.3 (Low: 1.5 - High: 7.0) & 4.25 \\
\hline 27 & Keep the team focused. & 5.7 (Low: 3.0 - High: 7.0) & 6.5 \\
\hline 28 & Knowledge of innovation process. & 6.5 (Low: 2.0 - High: 7.0) & 4.25 \\
\hline 29 & Listening to the team. & 5.9 (Low: 4.0 - High: 7.0) & 6.0 \\
\hline 30 & Not championing the team. & 4.3 (Low: 2.0 - High: 5.0) & 1.0 \\
\hline 31 & Not leading the team. & 4.2 (Low: 1.5 - High: 7.0) & 0.5 \\
\hline 32 & $\begin{array}{l}\text { Not taking credit of the team's } \\
\text { results. }\end{array}$ & 4.1 (Low: 2.5 - High: 7.0) & 6.5 \\
\hline 33 & $\begin{array}{l}\text { Not turning every team into Swedish } \\
\text { standard of personalities. }\end{array}$ & 2.8 (Low: 1.5 - High: 6.5) & 3.5 \\
\hline 34 & $\begin{array}{l}\text { Practical experience from building } \\
\text { innovation teams. }\end{array}$ & 5.4 (Low: 1.0 - High: 7.0) & 4.0 \\
\hline 35 & $\begin{array}{l}\text { Practical experience from innovation } \\
\text { work. }\end{array}$ & 4.5 (Low: 1.5 - High: 6.5) & 4.0 \\
\hline 36 & $\begin{array}{l}\text { Provide understanding of benefits of } \\
\text { creating temporary networks. }\end{array}$ & 3.0 (Low: 0.5 - High: 4.5 ) & 6.5 \\
\hline 37 & $\begin{array}{l}\text { Strengthen the self-confident to the } \\
\text { team to believe in what they're } \\
\text { doing. }\end{array}$ & 5.5 (Low: 3.0 - High: 6.0) & 6.25 \\
\hline 38 & $\begin{array}{l}\text { Support in methodology in picking } \\
\text { the right people. }\end{array}$ & 5.0 (Low: 3.5 - High: 7.0) & 5.5 \\
\hline 39 & $\begin{array}{l}\text { Supporting without bothering the } \\
\text { team. }\end{array}$ & 4.3 (Low: 1.0 - High: 7.0) & 6.5 \\
\hline 40 & Trust in the team. & 4.6 (Low: 3.0 - High: 7.0) & 7.0 \\
\hline
\end{tabular}

Table 3. The table demonstrates when in the Extended Innovation Process the facilitator's characteristics are important.

\begin{tabular}{lll}
\hline $\begin{array}{l}\text { Phase in the } \\
\begin{array}{l}\text { Extended } \\
\text { Innovation } \\
\text { Process }\end{array}\end{array}$ & $\begin{array}{l}\text { The importance of an innovation facilitator's characteristics in the different } \\
\text { phases of an ongoing innovation project in the Extended Innovation Process } \\
\text { according to the innovation teams and the sponsor. (The numbers below represent } \\
\text { the innovation facilitator's characteristics as ordered in Table 1.) }\end{array}$ \\
\hline & \multicolumn{1}{c}{ Innovation team } & \multicolumn{1}{c}{ Sponsor } \\
\hline Pre-phase & $20,26,28,34,35,38$ & $1,8,9,10,15,16,17,19,20,21,22,24$, \\
& & $26,28,30,31,33,34,35,36,37,38$ \\
Search & $4,5,8,9,10,11,13,15,16,17,21$, & $2,4,7,11,12,13,18,25,29$ \\
& $22,23,24,29,30,33,40$ & \\
Select & $1,2,3,6,7,12,14,18,19,25,27,31$, & $3,5,6,14,17,40$ \\
& $36,37,29$ & $27,32,39$ \\
Implement & 32 & (Out of scope) \\
Capture & (Out of scope) &
\end{tabular}


The importance of the facilitator's characteristics varied over time in those innovation projects (Figure 6) where the facilitator needed to both be involved in the team and support it by observing activities and advising on forthcoming activities throughout the innovation project. However, activities where the facilitator was expected to be involved in the team decreased during the innovation project, and activities of "back-office" character increased during the innovation project. This was explicitly expressed in terms of, for example, "Supporting without bothering", "Not championing the team", "Not leading the team", "Trust in the team" and "Ability to steer the team back on track when needed". This development was highly connected not only to the teams' learning curve of innovation knowledge but also to the fact that activities in the latter part of the innovation process were less abstract and more similar to what members in an innovation team can relate to in their everyday work; for example, when the innovation project enters the implementation phase, much of the abstract problem identification and problem solving are replaced with practical and hands-on work, such as ordering and assembling physical components. Still, innovation teams have to maintain the innovative mind-set and be ready to radically change plans for upcoming roadblocks or changing market demands.

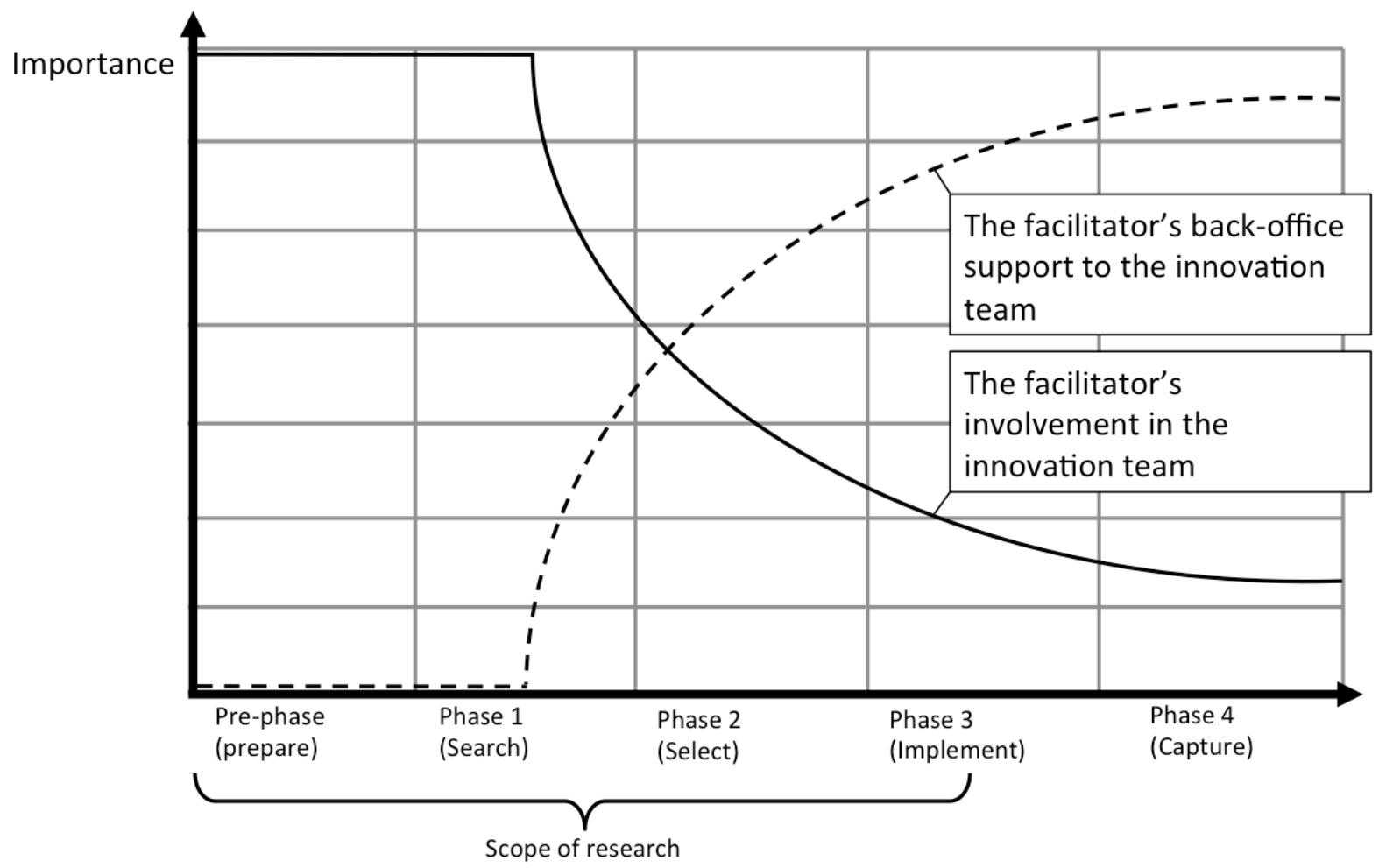

Fig. 6. The figure demonstrates how the facilitator's activities, involvement, and presence in innovation teams change during an ongoing innovation project.

The teams' learning curve from the innovation projects was significant. The interviews revealed that the first (Search) and the second (Select) phase of the innovation projects were very abstract and confusing for the team members, and they responded by arguing that they wasted time on useless work because they were used to being provided with already prepared specifications or 
requirements. In the innovation projects within this study, they had to figure out all of these things by themselves by following the innovation process, which includes working on parallel tracks to find out the best solution as the innovation project emerged. In the third phase (Implementation), the team members understood the purpose of previous activities, such as need-finding, and realised that they had saved both time and resources from the work conducted. Other values created were that they had fun while working, their motivation increased, and they explicitly said that they were ready for new innovation projects. In fact, Team B and Team C, who ended their innovation projects before Team A, started new innovation projects in which the facilitator was present as "back-office-support" to the convener.

The facilitator was seen as important or even crucial during the pre-phase and the first two phases of the innovation process, during which the facilitator needs to posses the ability to judge the current situation in order to adjust advice relevant to the given situation, which could vary over time or from project to project. On this basis, four areas of intertwined competences appeared (Figure 7) that the facilitator must be able to handle and educate and advise in: the innovation team creation process, through which the team is created and kicked off; the innovation team model, where the facilitator educates and advises the innovation team on team emergence processes and how they relate to the individuals and the overall organisation; the innovation process, during which the facilitator educates and advises in activities to consider and to plan for, depending on what phase the innovation work is in; and factors that enable innovation work, the facilitator highlighting factors for the innovation team and the sponsor to focus on, which enable the team to conduct the innovation work.

Further, three themes emerged for how the areas of competences were handled by the facilitator when working with the innovation teams: innovation-related knowledge (innovation knowledge), that is, theoretical knowledge of how to conduct innovation work and factors that enable innovation work, innovation management, and practical experience from previous innovation work; innovation-related knowledge management (knowledge management), that is, the ability for the facilitator to transform innovation knowledge into both advice related to innovation work and skills to guide an innovation team according to that advice, all based on the current situation; knowledge transfer, that is, the ability to transfer innovation knowledge and knowledge management to innovation teams through, for example, education, practical advice, and continuous feedback on progress. 


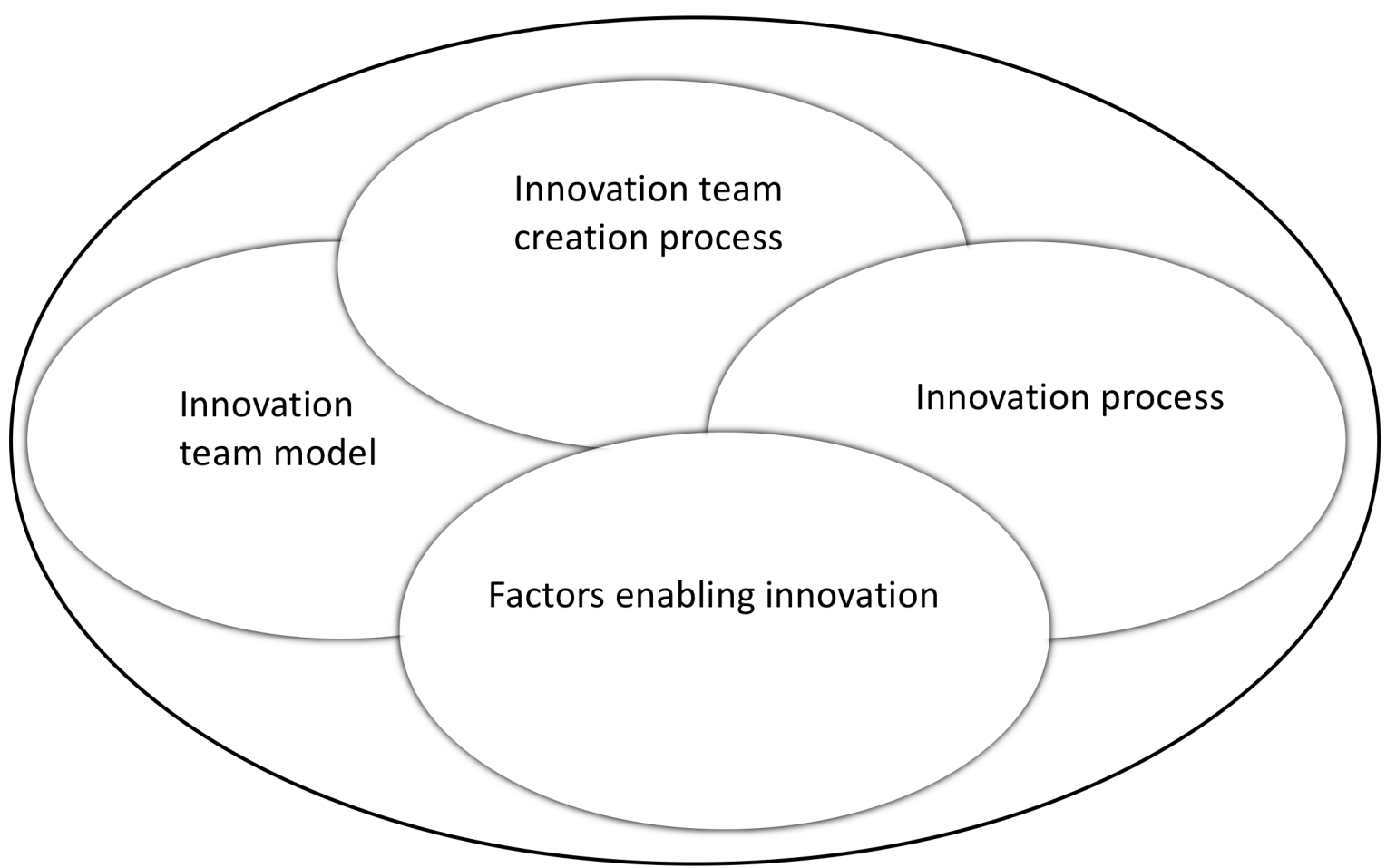

Fig. 7. The figure demonstrates the facilitator's areas of competence.

An unexpected finding was the importance of the pre-phase to the innovation process, in which the facilitator played a significant role when preparing the sponsor and the convener for the forthcoming work and advising the convener which team member to aim for when gathering the innovation team. The time spent in the pre-phase enabled the teams to kick off successfully without any signs of team development problems. The teams handled problems that occurred during the teams' work as a team, not blaming problems on each other but solving them as a team. The pre-phase's purpose was to prepare and allow time for the sponsor, management, and convener to accept the forthcoming work and plan for next steps without being stressed by feelings of unnecessary uncertainty. This resulted in the Extended Innovation Process, demonstrated below (Figure 8; Figure 9). 


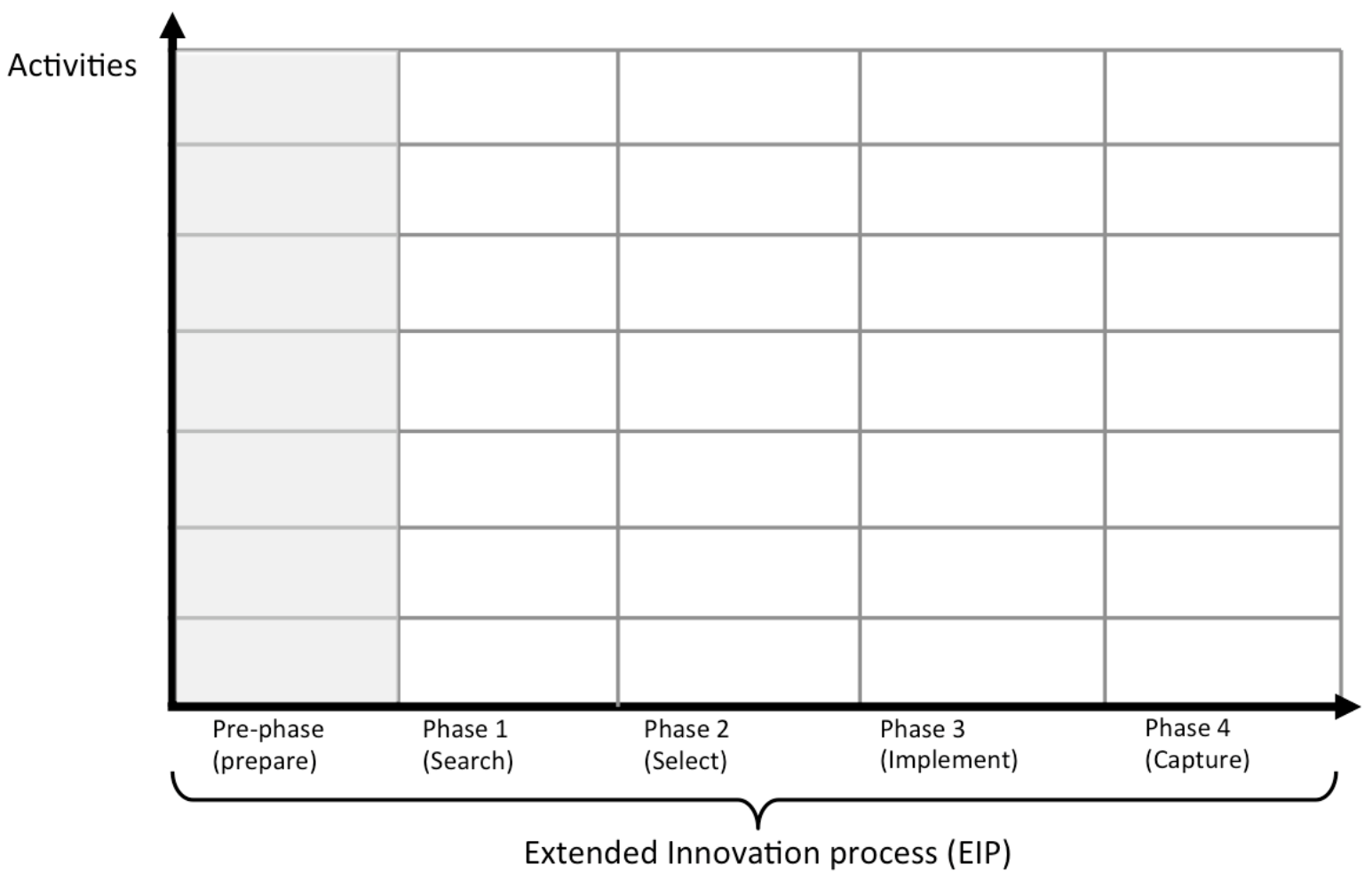

Fig. 8. The figure demonstrates the pre-phase in light grey as an extension of the innovation process illustrated as a work chart, in this case as an extension of the innovation process by Tidd and Bessant (2009) as used within this study.

The Extended Innovation Process (EIP) (Figure 9) is based on the general demonstration of well-established innovation processes and consists of four iterative phases. During the pre-phase, the innovation team is created accordantly in an attempt to avoid group development problems and prepare for forthcoming innovation work. The operational innovation work is begun next, in the ideation phase. This work is characterised by a high level of creativity and abstract work, as ideas are generated and selected based on the overall business strategy. In the execution phase, the practical development work is conducted, comprising work related to design, prototyping, testing, and evaluating the product or service. This phase also involves preparation for production and launch on the market. Last, the value harvesting phase, is where values created from the innovation project are captured. Value is relative and must be defined for each innovation project. Additionally, as the EIP is an iterative process, values must be harvested during each phase of the EIP as the innovation projects emerge towards market launch. However, the first phase regarding preparation is preferably not iterative if not needed due to unexpected circumstances, as illustrated by the densely dashed line and the dashed arrow back from the ideation phase to the preparation phase: 


\section{The Extended Innovation Process}

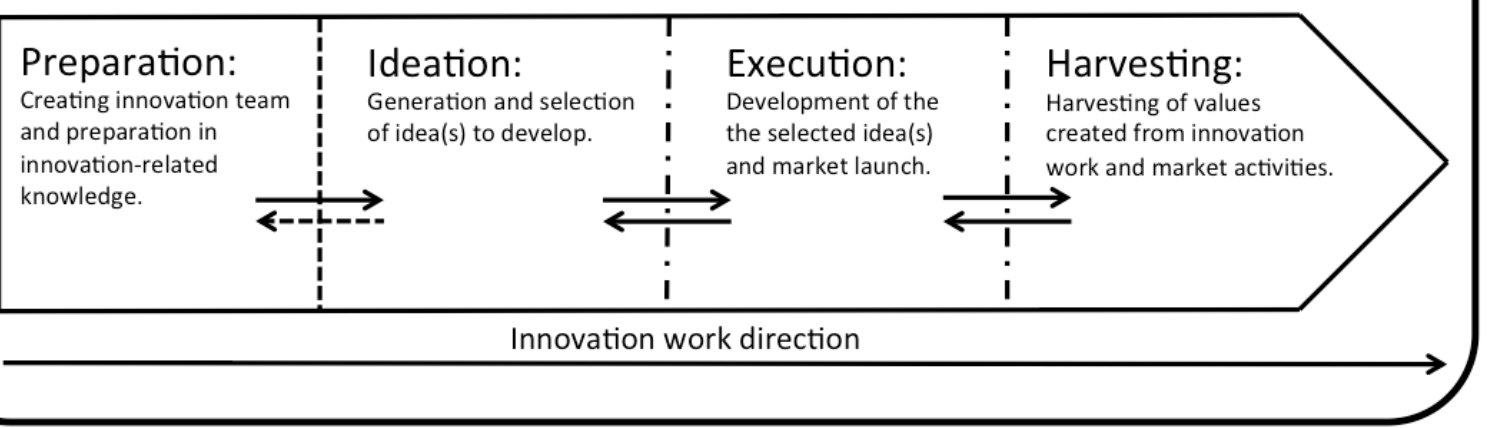

Fig. 9. The Extended Innovation Process (EIP).

\section{Discussion and Conclusion}

This section discusses four main findings and their contribution to prior research, and it also concludes the research. In the latter part of the section, practical implications are suggested. The four findings are:

- the Extended Innovation Process

- the facilitator's characteristics and importance for innovation teams

- innovation teams' learning effects

- the facilitator's areas of competence.

The Extended Innovation Process

A significant finding and the biggest but also most surprising contribution to prior research is the need for both a preparation phase in the innovation process and a facilitator's presence and involvement in the phases in which this research shows that the facilitator's presence and involvement has the largest impact on the forthcoming work. Both the preparation before the project has begun and the abstract ideation phase are apparently the most complicated for employees inexperienced in innovation management to handle. This has led to the conclusion that the innovation process as established today should be extended with a pre-phase, the Extended Innovation Process (EIP). This research investigated innovation teams conducting real innovation projects, in contrast to Räsänen et al., who suggested a theoretical framework based on Milton and Rogers's (2013) innovation process. This research contributes to prior research in the sense that the facilitator's competence was significantly important before the innovation process originally begins (Amabile et al., 1996; Baxter, 2002; Farris, 1972; Johnsson, 2009; Milton and Rogers, 2013; Tidd and Bessant, 2009; Trott, 2012). In other words, the preparation phase was revealed not only as an important phase for the facilitator to address management, convener, and sponsor about forthcoming innovation work but also as an additional step to the innovation processes presented; it served as a tool to help avoiding the group developing problems which are very common for newly formed teams (Tuckmann and Jensen, 1977; Whelan, 2013).

The facilitator's characteristics and importance for innovation teams 
This research revealed characteristics considered to be important for a facilitator to possess when facilitating innovation teams, which relate to previous research by providing a picture of the facilitator's role for innovation teams in ongoing innovation projects. The identified characteristics of a facilitator are similar to the characteristics to possess when conducting innovation work when it comes to, for example, social skills, handling uncertainty, and building trust (Du Chantenier, 2010; Han and Hovav, 2012; Heikkinen et al., 2007; Kadefors, 2003; Maurer, 2010; Smyth et al., 2010; Vincenzo and Mascia, 2011). The findings also relate to prior research regarding the ability to handle accurate tools, provide training (Andrew and Sirkin, 2008; Barnes and Francis, 2006), and not champion the team (Howell et al., 2004) but guide it in the complex innovation process (Hunter and Cuschenbery, 2011).

However, as the first two phases in the innovation process were assessed to be abstract and sometimes frustrating for the teams, the facilitator must work to avoid team stress, which otherwise will have a negative effect on team performance (Lee and Sukoco, 2011). The same applies to competence (Illeris, 2013) and innovation competence (Bozic, 2016) in the sense that a facilitator needs to possess certain skills and experience and to handle the complex situation of content and inter-and intrapersonal aspects to be successful. The biggest deviations in this research in relation to Illeris and Bozic's suggestions of competences to possess when conducting innovation work is that a facilitator, according to this research, should not be a champion, according to the team members within this study. The sponsor, on the other hand, supported that a facilitator should possess these characteristics, which may be a subject for further research. Additionally, this study revealed that the facilitator has to handle very complex situations, for example, steering the team back on track when needed but not disturbing the team. The research of Räsänen et al. (2015) has suggested a theoretical framework regarding when certain competences are needed in an innovation process. Their results provide a general picture of skills to possess when conducting innovation work in different phases of the innovation process. This research contributes to their research by means of very specific skills and experience regarding the facilitation of innovation teams' work, for which previous research demonstrates clusters of competence areas in general. Barnes and Francis' (2006) research on the OD practitioner suggests, on the other hand, a relatively detailed description of skills and knowledge to possess. However, this research contributes more competence to possess in certain phases of the innovation process; most importantly, this research highlights the need of possessing innovation-related knowledge in theory and practice.

Innovation teams' learning effects

This research demonstrates that the facilitator as a teacher of practical innovation work had positive effects on learning, as two of the teams started new innovation projects in which the facilitators' presence was more of a back-office support. This effect relates to the preparation phase in the EIP, as this is where the teaching begins: by educating not only the management, sponsor, and convener in becoming the innovation team but also the innovation team members, as they are invited to the innovation team and facilitated through the project. This finding contributes to research regarding innovation drivers (Hallgren, 2009; Johnsson et al., 2010) and champions (Dulaimi et al., 2004; Gamatese and Hallowell, 2011; Radnor and Robinson, 2000), in which the learning outcomes have not been satisfying. In this research, the innovation teams were able to start up new innovation projects based on their increased knowledge. However, the 
majority of the team members were the same in the new innovation projects, which eased the understanding of tasks to do in complex innovation work. The result would probably not have been the same with completely new innovation teams, or if the majority of the team members were new, due to the new team constellation (Wheelan, 2013) and potential lack of innovation related knowledge.

The facilitator's areas of competence

The characteristics were identified and their importance confirmed by one sponsor and three innovation teams that had been assisted by the same facilitator in a comparable context and set-up. The identified characteristics demonstrate both abilities and tasks for a facilitator to conduct during an ongoing innovation project, which were organised in competence areas covering models and processes related to innovation teams and factors that enable innovation. The areas of competence that a facilitator needs to possess relate to Bozic's (2016) research on innovation competence in the sense that she highlights the need for transitional knowledge for individuals who are going to conduct innovation work. Further, it also relates to Adams and Sirkin's (2008) research, as they demonstrate the need to be able to, for example, educate, be knowledgeable in toolkits, and advise. Further, this research also contributes to Bloch-Poulsen's (2011) research by means of adding innovation-related content to a discussion in order to educate team members if they are inexperienced in the matter. However, this research provides a richer content and adds the perspective of "what to do" and "when to act" to educate and increase the team members' competence for ongoing and future innovation projects.

Additionally, in one aspect, the facilitator him- or herself could be seen as enabling innovation teams, because the presence and involvement by giving advice from time to time to the conveners served as energy to the teams to continue working in times when, for example, they struggled from uncertainty or lack of dedication or resources. According to the team members and the sponsor, the innovation work would not have been able to proceed without the facilitator, especially not in the first two phases of the innovation process. This was highlighted in previous research by Johnsson (2016a; 2016b) but was confirmed in the current research.

This research has identified the required characteristics of an innovation facilitator (facilitator) when supporting innovation teams; it has also identified at which points in an innovation project these characteristics are most important. In this work, it was revealed that the facilitator should not only have a certain attitude, personal skills, and experience from innovation management, he or she should also be knowledgeable in group dynamic process and understand the situation from a holistic system perspective. Further, the research points to the importance of extending the innovation process with a preparation phase to ensure that a new innovation team has a fair chance to do a good job, as it is in the preparation phase that the team members have the opportunity to educate themselves at a stage where they do not waste time and energy.

The deviations between the sponsor's and the teams' opinion as to when the facilitator's characteristics were most needed provided an understanding that the sponsor saw an opportunity to avoid forthcoming problems by planning and preparing an innovation team in advance. The teams, on the other hand, presented a picture of when the facilitator should execute his or her skills relating to the activities in the innovation project. The practical implication of this knowledge is that a facilitator could work closely with the convener on tasks that match the present and forthcoming work in the innovation project. The benefit would be to avoid information 
overload and disturbance, which is related to "supporting without bothering the team". On the other hand, a convener must have a holistic view (Bozic, 2016; Illeris, 2013), which means that a facilitator needs to provide the convener with rich information in advance. Therefore, a facilitator must pay careful attention to indications of information overload to avoid setbacks.

When one understands that a facilitator's presence and involvement in the preparation phase and the first phases of the innovation project is of essence, it increases the chances of creating a successful innovation team that does not waste time or resources. This knowledge may be useful when allocating project resources and when planning the start of new innovation teams.

The results from this study show positive learning effects that could be used to develop educating programs for innovation facilitation within companies or consultancy firms. The education could be used to identify appropriate individuals to be educated to become new facilitators who could teach conveners to create innovation teams.

The Extended Innovation Process includes the preparation phase and allows an increased understanding that preparation is needed, but it could also serve as a visual tool for planning activities in forthcoming innovation work.

\section{Limitations and future research}

This qualitative study has involved three innovation teams in which the researcher has acted as a facilitator to all the teams, which may be a risk due to bias and therefore affect the results negatively. This risk was known in the research design, and actions were taken to avoid bias by carefully planning the research and highlighting this concern in the interviews to strengthen the validity and the reproducibility of the research. The results demonstrate that the facilitator's role was more important and complex than expected, knowledge that may be useful when guiding, advising, and teaching innovation teams in their innovation work. However, overall this research demonstrates a very complex situation for a facilitator to handle, but the innovation teams showed positive learning outcomes within this study. Nevertheless, the findings are based on a limited number of teams and respondents, which calls for attention when generalising the results. Therefore, further research is suggested on the facilitator's characteristics and on how the facilitator could be a teaching tool for new facilitators and conveners. Further, the Extended Innovation Process was unexpectedly identified during this research; therefore, future research is suggested in which its functionality and importance could be studied.

\section{Acknowledgements}

KK-stiftelsen (The Knowledge Foundation), Blekinge Institute of Technology and associated companies to this research: Auralight, Avalon Innovation, Dynapac Compaction Equipment, Holje International Group, Industrigruppen Karlskrona, Tech Network, Tetra Pak Packaging Solutions AB, GKN Aerospace Engine Systems and Volvo Construction Equipment. The organisations and companies above funded this study. 


\section{References}

Adkins, L. (2010). Coaching Agile Teams: A Companion for ScrumMasters, Agile Coaches, and Project Managers in Transition. Massachusetts: Courier.

Akbar, H. \& Tzokas, N. (2013). Charting the organisational knowledge creation process: An innovation-process perspective. Journal of Marketing Management, 29(13-14), 1592-1608.

Amabile, T., Conti, R., Coon, H., Lazenby, J., \& Herron, M. (1996). Assessing the work environment for creativity. Academy of Management Journal, 39(5), 1154-1134.

Andrew, J. P. \& Sirkin, H. L., (2008). Aligning for innovation. Global Business and Organizational Excellence, 27(6), 21-39.

Barczak, G., Griffin, A. \& Kahn K. B. (2009). Perspective: trends and drivers of success in NPD practices: results of the 2003 PDMA best practices study. Journal of product innovation management, 26(1), 3-23.

Barnes, B.K. \& Francis, D. (2006). The OD Practitioner as Facilitator of Innovation. In: The OD Network Conference. San Fransicso, USA.

Baxter, M. (2002). Product Design. Cheltenham. UK: Nelson Thornes Ltd.

Bessant, J. (2003). High involvement innovation: building and sustaining competitive advantage through continuous change. West Sussex: John Wiley \& Sons Ltd.

Blessing, L. \& Chakrabarti, A. (2009). DRM, a Design Research Methodology. London: Springer London Ltd.

Bloch-Poulsen, J. (2011) September. Dialogic Dissensus Approach-a Model for Research Based Facilitation of Innovation? In: The 6th European Conference on Innovation and Entrepreneurship.

Boyatzis, R. E. (1998). Transforming Qualitative Information: Thematic analysis and code development. USA, SAGE Publications Inc.

Bozic, N. Y. (2016). Integrated model of innovation competence. In: The 27th ISPIM Innovation Conference, Porto, Portugal.

Brenner, T. \& Broekel, T. (2011). Methodological issues in measuring innovation performance of spatial units. Industry and Innovation, 18(1) 7-37.

Buijs, J. (2007). Innovation Leaders Should be Controlled Schizophrenics. Journal Compilation, 16(2), 203-210.

Büschgens, T., Bausch A. \& Balkin D. (2013). Organizating for radical innovation - A multi-level behavioral approach. Journal of High Technology Management Research, 24(2), 138-152.

Chen, J., Damanpour F. \& Reilly R. R. (2009). Understanding antecedents of new product development speed: A meta-analysis. Journal of Operational Management, 28, 17-33.

Davison, G. \& Blackman D. (2005). The role of mental models in innovative teams. European Journal of Innovation Management, 8(4), 409-423.

Du Chatenier, E., Jos A. A. M, Verstegen J. A. A. M., Harm J. A., Biemans H. J. A., Mulder M. \& Omta O. S. W. F. (2010). Identification of competencies for professionals in open innovation teams. RED Management, 40(3), 271-280. 
Dulaimi, M. F., Nepal M. P. \& Park M. (2004). A hierarchical structural model of assessing innovation and project performance. Construction Management and Economics l, 23, 565-577.

Ellström, P.E. \& Nilsen P. (2014). Promoting Practice-Based Innovation Through Learning at Work. In: International Handbook of Research in Professional and Practice-based Learning, eds. Billett, Harties C. \& Gruber, H. 1161-1185. Dordrecht: Springer International Handbooks of Education.

Farris, G. F. (1972). The effect of individual roles on performance in innovative groups. $R \& D$ Management, 3(1), 23-28.

Gamatese, J.A. \& Hallowell M. (2011). Enabling and measuring innovation in the construction industry. Construction Management and Economics, 29, 553-567.

Gummesson, E. (2000). Qualitative Methods in Management Research. Second Edition. Sage Publications Inc.

Hallgren, E. W. (2009). How to Use an Innovation Audit as a Learning Tool: A Case Study of Enhancing High-Involvement Innovation. Creativity and Innovation Management, 18(1), 4858.

Han, J-Y. \& Hovav A. (2012). To bridge or to bond? Diverse social connections in an IS project team. International Journal of Project Management, 31, 378-390.

Heikkinen, M.T., Mainela, T., Still, J. \& Tähtinen, J. (2007). Roles for managing in mobile service development nets. Industrial Marketing Management, 36 (7), 909-925.

Highsmith, J. (2009). Agile Project Management: Creating Innovative Products. Crawfordsville: Addison-Wesley.

Howell, J.M., Shea, C.M. \& Higgins, C.A. (2005). Champions of product innovations: defining, developing, and validating a measure of champion behavior. Journal of Business Venturing, 20, 641-661.

Hunter, S. T. \& Cushenbery, L. (2011). Leading for Innovation: Direct and Indirect Influences. Advances in Developing Human Resources, 13(3), 248-265.

lleris, K. (2013). Kompetens. Lund: Studentlitteratur.

Johnsson, M. (2017), Creating High-performing Innovation Teams, Journal of Innovation Management. 5(4), 23-47.

Johnsson, M. (2009). Sälj skinnet innan björnen är skjuten. Kolbäck: Raft Förlag.

Johnsson, M. \& Karlsson, H. (2011). Existence of negative innovation-gaps affecting innovation performance in two Swedish SMEs. In: The $22^{\text {nd }}$ ISPIM Innovation Conference, Hamburg, Germany.

Johnsson, M., Ekman S., Wiktorsson M. \& Karlsson T. (2010). A model-based process for developing environmental innovations: Four cases where the RAFT-model has been used at environmental innovations. In: IASP Conference XXVII, Daedak, South Korea.

Johnsson, M. (2014). Innovation Teams: Before Innovation Work is Begun. In: The 25th ISPIM Innovation Conference, Dublin, Ireland.

Johnsson, M. (2016a). Important innovation enablers for innovation teams. In: The 27th ISPIM Innovation Conference, Porto, Portugal. 
Johnsson, M. (2016b). The importance of innovation enablers for innovation teams. In: The $23^{\text {rd }}$ EurOMA Conference, Trondheim, Norway.

Kadefors. A. (2003). Trust in project relationships - inside the black box. International Journal of Project Management, 22, 175-182.

Kairisto-Mertanen, L., Penttilä, T. and Nuotio, J. (2011), On the definition of innovation competencies, in: Torniainen, I., Mahlamäki-Kultanen, S., Nokelainen P. and Paul, I. (eds.), Innovations for competence management, Conference proceedings. Series C, reports and other current publications, part 83, Lahti University of Applied Sciences, Esa print Oy, pp. 25-33.

Karlsson, H., Johnsson M. \& Backström T. (2010). Interview Supported Innovation Audit: how does a complementary interview affect the understanding of an innovation audits results when the interview is based on the audit statements. In: The 3rd ISPIM Innovation Symposium, Quebec, Canada.

Kesting, P. \& Ulhöj J. P. (2010). Employee-driven innovation: extending the license to foster innovation. Management Decision, 48(1), 65-84.

Knight, L. \& Harland, C. (2005). Managing Supply Networks: Organizational Roles in Network Management. European Management Journal, 23(3), 281-292.

Kristiansen, M. \& Bloch-Poulsen J. (2010). Employee Driven Innovation in Team (EDIT) Innovative Potential, Dialogue. International Journal of Action Research, 6(2-3), 155-195.

Lee, L. T-S. \& Sukoco B. M. (2011). Reflexivity, stress, and unlearning in the new product development team: the moderating effect of procedural justice. RED Management, 41(4), 410423.

Martin, R.L (2011) The Innovation Catalysts. Harvard Business Review, June 2011.

Maurer, I. (2010). How to build trust in inter-organizational projects: The impact of project staffing and project rewards on the formation of trust, knowledge acquisition and product innovation. International Journal of Project Management, 28, 629-637.

Maxwell, J. A. (2013). Qualitative Research Design: An interactive Approach. Third edition, Thousand oaks, CA: Sage Publications.

McGreevy, M. (2006a). Team working: part 1 - an evaluation of current thinking. Industrial and commercial training, 38(5), 259-264.

McGreevy, M. (2006b). Team working: part 2 - how are teams chosen and developed. Industrial and commercial training, 38(7), 365-370.

Menon, A., Chowdhury, J. \& Lukas B. A. (2002). Antecedents and outcomes of new product development speed: An interdisciplinary conceptual framework. Industrial Marketing Management, 31, 317-328.

Milton, A. \& Rodgers P. (2013). Research methods for product design. London: Laurence King Publishing Ltd.

Mitchell, R. J. \& Boyle B. (2008). A theoretical model of transformational leadership's role in diverse teams. Leadership $\&$ Organization Development Journal, 30(5), 455-474.

O'Connor, G. C. \& McDermott C. M. (2004). The human side of radical innovation. Journal of Engineering and Technology Managememt, 21, 11-30. 
Radnor, Z. \& Robinson J. (2000). Benchmarking Innovation: A Short Report. Creativity and Innovation Management, 9, 3-13.

Räsänen, M., Putkonen A. \& Kairisto-Mertanen L. (2015). Innovation process-competences needed to make it succeed. In: CINet conference, Stockholm, Sweden.

Schraub, E. M., Michel A., Shemla M. \& Sonntag K. (2014). The roles of leader emotion management and team conflict for team members' personal initiative: A multilevel perspective. European Journal of Work and Organizational Psychology, 23(2), 263-276.

Schön, D. A. (1991). The reflective practitioner. Basic Books, New York.

Scozzi, B., C. Garavelli \& K. Crowson. 2005. Methods for modeling and supporting innovation processes in SMEs. European Journal of Innovation Management, 8(1), 120-137.

Smyth, H., Gustafsson M. \& Ganskau E. (2010). The value of trust in project business. International Journal of Project Management, 28, 117-129.

Tidd, J. \& Bessant, J. (2009). Managing Innovation - Integrating Technological, Market and Organizational Change, fourth edition. West Sussex: John Wiley \& Sons Ltd.

Trott. P. (2012). Innovation Management and New Product Development, Fifth edition. Essex, Pearson Education Ltd.

Tuckmann, B.W. \& Jensen, M.A.C. (1977). Stages of Small-Group Development Revisited. Group and Organization Management, 2, 419-427.

Vincenzo, F. Di \& Mascia D. (2011). Social capital in project-based organizations: Its role, structure, and impact on project performance International Journal of Project Management, 30, $5-14$.

West, M., Hirst, G., Richter A. \& Shipton H. (2004). Twelve steps to heaven: Successfully managing change through developing innovative teams. European Journal of Work and Organizational Psychology, 13(2), 269-299.

Wheelan, S. A. (2013). Creating Effective Teams - A Guide for Members and Leaders. Lund: Studentlitteratur AB.

Xu, Q., Chen, J., Xie, Z., Liu, J., Zheng, G. \& Wang, Y. (2006). Total Innovation Management: a novel paradigm of innovation management in the 21st century. Journal of Technology Transfer, $32,9-25$.

Yin, R. K., (2013). Case study research: Design and methods. Thousand Oaks, CA: Sage publications. 


\section{Biographies}

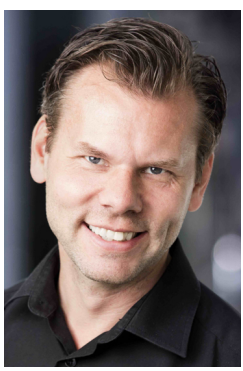

Mikael Johnsson. The author earned his Ph.D. with the thesis entitled Innovation Enablers and Their Importance for Innovation Teams in Mechanical Engineering at Blekinge Institute of Technology 2016, Karlskrona, Sweden. He earned his Licentiate degree in Innovation Management at Mälardalen University 2012, Eskilstuna, Sweden, and he earned his Bachelor of Science in Innovation Management 2006, Eskilstuna, Sweden. His research mainly focuses on high-performing innovation teams, where he develop theoretical frameworks and practical methodologies that both academia and the industry benefit of. Recent publications of Dr. Johnsson involves Creating High-performing Innovation Teams (Journal of Innovation Management, 2017), and Innovation Enabler for Innovation Teams (Journal of Innovation Management, 2017). Aside from the academic work, Dr. Johnsson is an innovator and author, and he is consulting as innovation management specialist where he supports organisations to improve their innovation management skills and performance.

\section{ISSN 2183-0606}

http://www.open-jim.org

http://creativecommons.org/licenses/by/3.0 